\title{
Geometrical- and Tooth Contact Analysis of the Areas and Perimeters on the Archimedean Worm Wheels Depending on the Modification of the Axial Module
}

Sándor Bodzás ( $\sim$ bodzassandor@eng.unideb.hu )

University of Debrecen

Gyöngyi Szanyi

University of Debrecen

\section{Research Article}

Keywords: worm, worm wheel, module, teeth, stress, deformation

Posted Date: July 12th, 2021

DOI: https://doi.org/10.21203/rs.3.rs-650763/v1

License: (c) (1) This work is licensed under a Creative Commons Attribution 4.0 International License.

Read Full License 


\title{
GEOMETRICAL- AND TOOTH CONTACT ANALYSIS OF THE AREAS AND PERIMETERS ON THE ARCHIMEDEAN WORM WHEELS DEPENDING ON THE MODIFICATION OF THE AXIAL MODULE
}

\author{
Dr. Sándor Bodzás¹, Dr. Gyöngyi Szanyi² \\ ${ }^{1}$ Ph.D., Vice Head of Department, Associate professor, ${ }^{2} \mathrm{Ph} . \mathrm{D}$. Assistant lecturer \\ ${ }^{1}$ Department of Mechanical Engineering, University of Debrecen, \\ ${ }^{2}$ Department of Basic Technical Studies, University of Debrecen \\ 4031 Debrecen, Ótemető str. 2-4., Hungary \\ *Email: ${ }^{1}$ bodzassandor@eng.unideb.hu, ${ }^{2}$ szanyi.gyongyi@ science.unideb.hu
}

\begin{abstract}
With the knowledge of the recommendations from reference literatures - six types of Archimedean worm gear drives were designed with the modification of the axial module. After that computer aided models were generated. These pairs were loaded by the same torque to analyse the mechanical parameters on the tooth contact zone. Due to the geometrical establishment, three teeth are connected with the worm surface at the same time, that is why these teeth are analysed. Polygon method was used to approach the kinematical impression on the worm wheel surface. As a result, we were able to define the area- and perimeter percentages of these impressions on the worm wheel surface for each tooth. We also determined the correlation between the axial module and the analysed mechanical parameters supposing average values on the contact surfaces.
\end{abstract}

Keywords: worm, worm wheel, module, teeth, stress, deformation

\section{INTRODUCTION}

Worm gear drives are widely used in the world for different engineering constructions providing high transmission ratio and perpendicular shaft position between the elements. In this case more teeth are connected at the same time that is why higher torque could be transferred than other cases of spur gear and bevel gear [1, 2, 4 - 9, 20, 21, 22, 24].

Although the manufacturing process of the worm wheel is complicated, it could be generated by direct motion mapping. It means the geometry of the worm defines the cutting tool, which is called a hob, which manufactures the teeth of the worm wheel [1, 4, 25, 26, 27]. From geometrical point of view, the worm and the hob are the same. The difference between them are addendum and tooth width. We should also provide clearances during the tooth connection to avoid heat deformations $[1,4,25,26,27]$.

F.L. Litvin found mathematical processes to determine and optimize the tooth contact areas in case of different gears. He designed special drives for different companies. His research group developed computer aided software for the geometrical designing and the localization of the contact area on toothed gears [6, 7, 23].

A. Fuentes Aznar and his research group deal with tooth contact analysis (TCA) which contains geometrical designing, computer aided modelling (CAD) and Finite Element Analysis (FEM) for standardized gear drives and special connecting elements [7]. The aim of the TCA is to determine the mechanical parameters on the tooth contact zone by different load forces and torques depending on the material type [7, 23].

I. Dudás researches the manufacturing development of the different worm gear drives. He also analyses these elements by mathematical way to provide the correct connection and 
manufacturing process for them. The development stages of the grinding processes are important for the assurance of the better connection and the reduction of the wearing between the kinematic pairs [4].

T. Bercsey analysed the connection of the globoid worm and hyperbolic gear. On the other hand, he proved the application of the kinematic method for toroidal gears $[2,3]$.

I. Sz. Krivenko invented the cylindrical worm gear drives having arched profile in axial section. Based on his experience, he recommended a certain designing process for this construction. The advantage of this geometry is the convex-concave teeth connection which results better contact lines and area than in case of linear profile [8].

V. Goldfarb works on the geometrical development of spiroid- and cylindrical worm gears by mathematical and constructional way. He analyses the contact mechanical parameters by FEM for the geometrical localization [13, 14].

The journal of Modeling the double worm-face gears [9] presents the matrix - vectorial mathematical model of the double worm-face gear with cylindrical worm and a graphical modelling which is based on the specific geometrical characteristics accomplished by means of the Autodesk Inventor 3D modelling program.

In his journal, M.V. Chernets [10] presents a computational method of worm gears with Archimedean and involute worms. Engagement correction is presented, based on the contact pressures and wear of tooth of the wheel, as well as the gear life and the sliding speed in the engagement.

In their international journal K. Kawasaki and I. Tsuji [11] shows a machining method of largesized cylindrical worm gears with Niemann profiles using a computer numerical control (CNC) machining center. The tooth contact pattern and transmission errors of large-sized worm gear pair with Niemann profiles are analysed before machining of the worm and worm wheel. After that, the machining conditions of the worm is determined by calculating each offset distance between the worm axis and the center axis of the end mill, and then the worm is machined by swarf cutting. That means machining by the side surface of the end mill.

In the Study on the influence of gear hobbing and shaft misalignments on the geometric interference of cylindrical worm gear set, [12] the author presents the results of the machine tool setting errors of the worm gear hobbing and its effects of the shaft misalignments of the worm gear set on the interference.

In the Meshing theory of mismatched ZC1 worm drive, [15] the contact endpoints, the datum point, and the internal momentary contact points are all determined by solving their corresponding nonlinear equation sets iteratively. The numerical results of the relative principal curvature, the transmission error, and the drive ratio error of the worm drive are all obtained.

J. Sohn, N. Park [17] present the geometric interference of cylindrical worm gear drives using an oversized hob to cut the worm gear. The momentary contact line of a fully conjugated gear set becomes a momentary point of contact when an oversized hob is used.

An Academic writing [18] presents a novel point-contact hourglass worm drive consisting of an involute helical beveloid (IHB) gear and an oblique planar enveloping (OPE) hourglass worm - as a result of the increasing requirements of high-precision and high bearing capacity in industrial robot and aerospace technology.

\section{GENERATION- AND THE GEOMETRY OF ARCHIMEDEAN WORMS}

The worm surface is generated by such cutting tool which has straight-lined blade. This cutting edge is situated in the axial section of the worm $[4,6,7,20,26,27,28]$. The generating lines are in coordinate system $\mathrm{C}_{\mathrm{p}}$, which is connected to the edge of the tool. This coordinate system does rotational and linear motion at the same time, which generate helical surface of the worm 
(Figure 1) $[4,6,7,20,26,27,28]$. The transformation matrix between the $\mathrm{C}_{0}$ and $\mathrm{C}_{1 \mathrm{R}}$ systems is:

$$
M_{1 R, 0}=\left[\begin{array}{cccc}
\cos \theta & -\sin \theta & 0 & 0 \\
\sin \theta & \cos \theta & 0 & 0 \\
0 & 0 & 1 & \pm p \cdot \theta \\
0 & 0 & 0 & 1
\end{array}\right]
$$

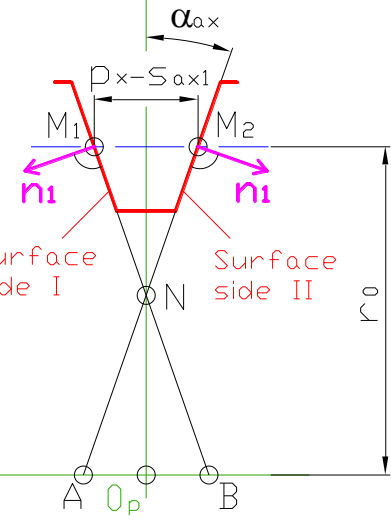

a)

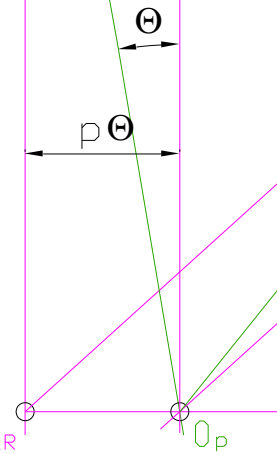

b)

Figure 1. Geometry of the cutting edge (a) and coordinate transformation (b)

Based on Figure 1, the normal unit vector is [7]:

$$
\vec{n}_{1 R}(\eta, \theta)=\frac{\partial \vec{r}_{1 R}}{\partial \eta} \times \frac{\partial \vec{r}_{1 R}}{\partial \theta}
$$

The generated surface on the $\mathrm{C}_{1 \mathrm{R}}$ coordination system is:

$$
\vec{r}_{1 R}(\eta, \theta)=M_{1 R, p}(\theta) \cdot \vec{r}_{p}(\eta)
$$

In case of right-hand worm, side I surface is:

$$
\left.\begin{array}{c}
x_{1 R I}=\eta \cdot \cos \alpha_{a x} \cdot \cos \theta \\
y_{1 R I}=\eta \cdot \cos \alpha_{a x} \cdot \sin \theta \\
z_{1 R I}=-\eta \cdot \sin \alpha_{a x}+\left(r_{0} \cdot \tan \alpha_{a x}-\frac{p_{x}-s_{a x 1}}{2}\right)+p \cdot \theta
\end{array}\right\}
$$

The surface unit normal vector of side I surface is:

$$
\begin{gathered}
\vec{n}_{1 R I}(\eta, \theta)=\left(p \cdot \sin \theta+\eta \cdot \sin \alpha_{a x} \cdot \cos \theta\right) \cdot \vec{\imath} \\
-\left(p \cdot \cos \theta-\eta \cdot \sin \alpha_{a x} \cdot \sin \theta\right) \cdot \vec{\jmath}+\eta \cdot \cos \alpha_{a x} \cdot \vec{k}
\end{gathered}
$$


In case of right-hand worm, side II surface is:

$$
\left.\begin{array}{c}
x_{1 R I I}=\eta \cdot \cos \alpha_{a x} \cdot \cos \theta \\
y_{1 R I I}=\eta \cdot \cos \alpha_{a x} \cdot \sin \theta \\
z_{1 R I I}=\eta \cdot \sin \alpha_{a x}-\left(r_{0} \cdot \tan \alpha_{a x}-\frac{p_{x}-s_{a x 1}}{2}\right)+p \cdot \theta
\end{array}\right\}
$$

The surface unit normal vector of side II surface is:

$$
\begin{gathered}
\vec{n}_{1 R I I}(\eta, \theta)=\left(p \cdot \sin \theta-\eta \cdot \sin \alpha_{a x} \cdot \cos \theta\right) \cdot \vec{\imath} \\
-\left(p \cdot \cos \theta+\eta \cdot \sin \alpha_{a x} \cdot \sin \theta\right) \cdot \vec{\jmath}+\eta \cdot \cos \alpha_{a x} \cdot \vec{k}
\end{gathered}
$$

If $\mathrm{y}_{1 \mathrm{R}}=0$, the equations of the two sections are $\mathrm{x}_{1 \mathrm{R}}=\mathrm{x}_{1 \mathrm{R}}(\eta)$ and $\mathrm{z}_{1 \mathrm{R}}=\mathrm{z}_{1 \mathrm{R}}(\eta)$ :

$$
\left.\begin{array}{c}
x_{1 R}=\eta \cdot \cos \alpha_{a x} \\
y_{1 R}=0 \\
z_{1 R}=\eta \cdot \sin \alpha_{a x}-\left(r_{0} \cdot \tan \alpha_{a x}-\frac{p_{x}-s_{a x 1}}{2}\right)
\end{array}\right\}
$$

or

$$
\left.\begin{array}{c}
x_{1 R}=-\eta \cdot \cos \alpha_{a x} \\
y_{1 R}=0 \\
z_{1 R}=\eta \cdot \sin \alpha_{a x}-\left(r_{0} \cdot \tan \alpha_{a x}-\frac{p_{x}-s_{a x 1}}{2}\right)+p \cdot \pi
\end{array}\right\}
$$

The contact point between the connecting elements could be calculated by the Fundamental Law of gear-tooth action [6, 7]:

$$
\overrightarrow{n_{1 R}} \cdot \overrightarrow{v_{1 R}}=0
$$

The formula (10) could also be used to determine surface of the worm wheel if the worm surface is known [1, $4-7,22,23,25,27]$.

\section{DESIGN- AND MODELLING PROCESS}

Based on the recommendations of the reference literature $[4-8,13,14,16,20,21,27]$ six types of Archimedean worm gear drives are designed by different axial modules. All the other input parameters are unchanged (f', $\left.\mathrm{c}^{*}, \mathrm{r}^{\prime}, \mathrm{z}_{1}, \mathrm{z}_{2}, \mathrm{~L}, \mathrm{~b}_{2}, \mathrm{\alpha}_{\mathrm{n}}, \mathrm{j}\right)$. The geometrical calculations are created by GearTeq software (Table 1).

Table 1. The calculated parameters of the designed worm gear drives

\begin{tabular}{|l|c|c|c|c|c|c|}
\hline $\begin{array}{l}\text { The parameters of the } \\
\text { worm gear drive }\end{array}$ & I. & II. & III. & IV. & V. & VI. \\
\hline Axial module $\left(\mathrm{m}_{\mathrm{ax}}\right)[\mathrm{mm}]$ & 6.5 & 7 & 8 & 9 & 10 & 11 \\
\hline Diametral pitch $\left(\mathrm{p}_{\mathrm{d}}\right)[\mathrm{mm}]$ & 3.907 & 3.628 & 3.175 & 2.822 & 2.54 & 2.309 \\
\hline $\begin{array}{l}\text { Normal diametral pitch }\left(\mathrm{p}_{\mathrm{dn}}\right) \\
{[\mathrm{mm}]}\end{array}$ & 4.022 & 3.751 & 3.314 & 2.978 & 2.712 & 2.497 \\
\hline
\end{tabular}




\begin{tabular}{|c|c|c|c|c|c|c|}
\hline Normal module $\left(\mathrm{m}_{\mathrm{n}}\right)[\mathrm{mm}]$ & 6.315 & 6.77 & 7.662 & 8.527 & 9.363 & 10.168 \\
\hline $\begin{array}{l}\text { Worm lead of thread }\left(\mathrm{p}_{\mathrm{x}}\right) \\
\text { [mm] }\end{array}$ & 61.3 & 66 & 75.4 & 84.8 & 94.2 & 103.7 \\
\hline $\begin{array}{l}\text { Circular pitch of the worm- } \\
\text { wheel }\left(\mathrm{t}_{0}\right)[\mathrm{mm}]\end{array}$ & 20.4 & 22 & 25.1 & 28.3 & 31.4 & 34.6 \\
\hline Lead angle $\left(\gamma_{\mathrm{m}}\right)[\mathrm{mm}]$ & 13.7 & 14.7 & 16.7 & 18.6 & 20.6 & 22.4 \\
\hline Addendum coefficient (f') & \multicolumn{6}{|c|}{1} \\
\hline Clearance coefficient $\left(\mathrm{c}^{*}\right)$ & \multicolumn{6}{|c|}{0.2} \\
\hline Fillet coefficient $\left(\mathrm{r}^{\prime}\right)$ & \multicolumn{6}{|c|}{0.3} \\
\hline Number of threads $\left(\mathrm{z}_{1}\right)$ & \multicolumn{6}{|c|}{3} \\
\hline $\begin{array}{l}\text { Number of teeth of the } \\
\text { worm-wheel }\left(\mathrm{z}_{2}\right)\end{array}$ & \multicolumn{6}{|c|}{28} \\
\hline Direction of the wheel & \multicolumn{6}{|c|}{ right hand } \\
\hline $\begin{array}{l}\text { Pitch diameter of the worm } \\
\left(\mathrm{d}_{01}\right)[\mathrm{mm}]\end{array}$ & \multicolumn{6}{|c|}{80} \\
\hline $\begin{array}{l}\text { Pitch diameter of the worm- } \\
\text { wheel }\left(\mathrm{d}_{02}\right)[\mathrm{mm}]\end{array}$ & 182 & 196 & 224 & 252 & 280 & 308 \\
\hline $\begin{array}{l}\text { Outside diameter of the } \\
\text { worm }\left(\mathrm{d}_{\mathrm{a} 1}\right)[\mathrm{mm}]\end{array}$ & 93 & 94 & 96 & 98 & 100 & 102 \\
\hline $\begin{array}{l}\text { Outside diameter of the } \\
\text { worm-wheel }\left(\mathrm{d}_{\mathrm{a} 2}\right)[\mathrm{mm}]\end{array}$ & 199.8 & 214.9 & 245.1 & 275.3 & 305.5 & 335.7 \\
\hline Center distance (a) [mm] & 131 & 138 & 152 & 166 & 180 & 194 \\
\hline $\begin{array}{l}\text { Face width of the worm- } \\
\text { wheel }\left(b_{2}\right)[\mathrm{mm}]\end{array}$ & \multicolumn{6}{|c|}{50} \\
\hline Worm length $(\mathrm{L})[\mathrm{mm}]$ & \multicolumn{6}{|c|}{200} \\
\hline Pressure angle $\left(\alpha_{\mathrm{ax}}\right)\left[^{\circ}\right]$ & 20.5 & 20.6 & 20.8 & 21 & 21.2 & 21.5 \\
\hline $\begin{array}{l}\text { Normal pressure angle }\left(\alpha_{n}\right) \\
{\left[{ }^{\circ}\right]}\end{array}$ & \multicolumn{6}{|c|}{20} \\
\hline $\begin{array}{l}\text { Addendum of the worm }\left(\mathrm{h}_{\mathrm{a} 1}\right) \\
\text { [mm] }\end{array}$ & 6.5 & 7 & 8 & 9 & 10 & 11 \\
\hline $\begin{array}{l}\text { Addendum of the worm- } \\
\text { wheel }\left(\mathrm{h}_{\mathrm{a} 2}\right)[\mathrm{mm}]\end{array}$ & 6.5 & 7 & 8 & 9 & 10 & 11 \\
\hline $\begin{array}{l}\text { Dedendum of the worm }\left(\mathrm{h}_{\mathrm{f} 1}\right) \\
\text { [mm] }\end{array}$ & 7.6 & 8.2 & 9.3 & 10. & 11.7 & 12.8 \\
\hline $\begin{array}{l}\text { Dedendum of the worm- } \\
\text { wheel }\left(\mathrm{h}_{\mathrm{f} 2}\right)[\mathrm{mm}]\end{array}$ & 7.6 & 8.2 & 9.3 & 10.5 & 11.7 & 12.8 \\
\hline $\begin{array}{l}\text { Tooth thickness of the worm } \\
\left(\mathrm{S}_{\mathrm{ax} 1}\right)[\mathrm{mm}]\end{array}$ & 10.2 & 11 & 12.6 & 14.1 & 15.7 & 17.3 \\
\hline $\begin{array}{l}\text { Tooth thickness of the } \\
\text { worm- wheel }\left(\mathrm{S}_{\mathrm{ax} 2}\right)[\mathrm{mm}]\end{array}$ & 9.2 & 10 & 11.6 & 13.1 & 14.7 & 16.3 \\
\hline Fillet radius $(\mathrm{r})[\mathrm{mm}]$ & 1.9 & 2.1 & 2.4 & 2.7 & 3 & 3.3 \\
\hline Backlash (j) [mm] & \\
\hline Transmission ratio (i) & \multicolumn{6}{|c|}{$3 / 28$} \\
\hline Diameter ratio (q) & \multicolumn{5}{|c|}{10} & 11 \\
\hline
\end{tabular}




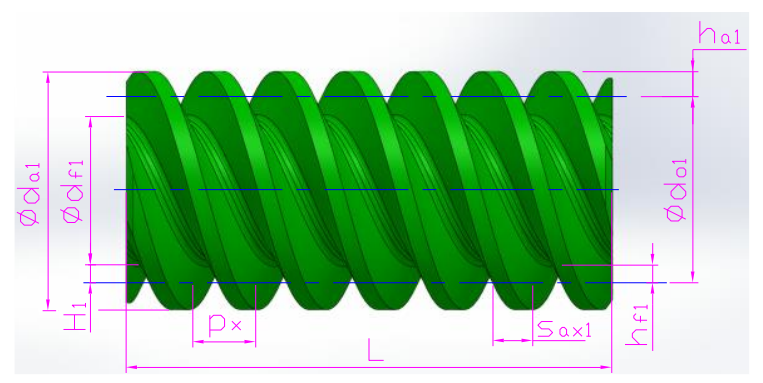

a) worm geometry

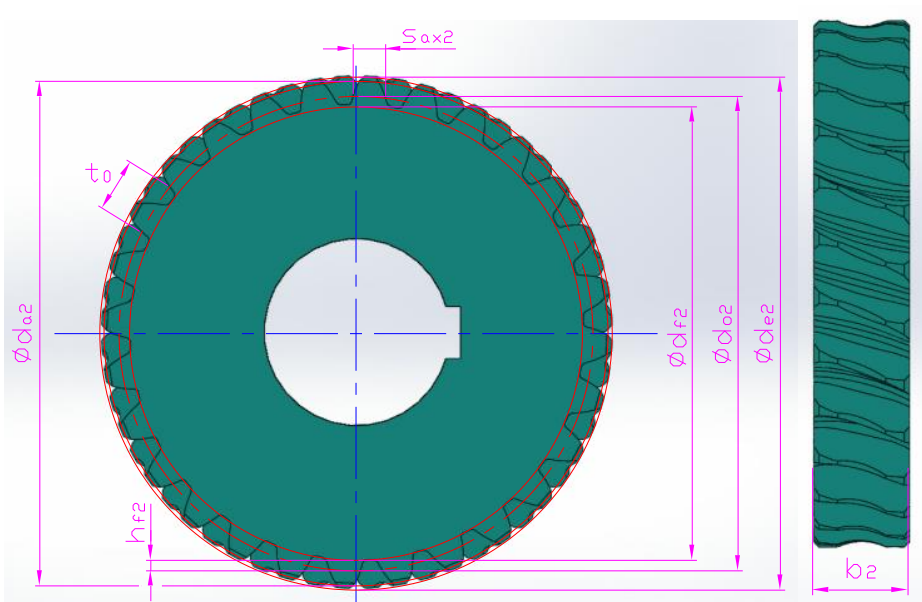

b) worm wheel geometry

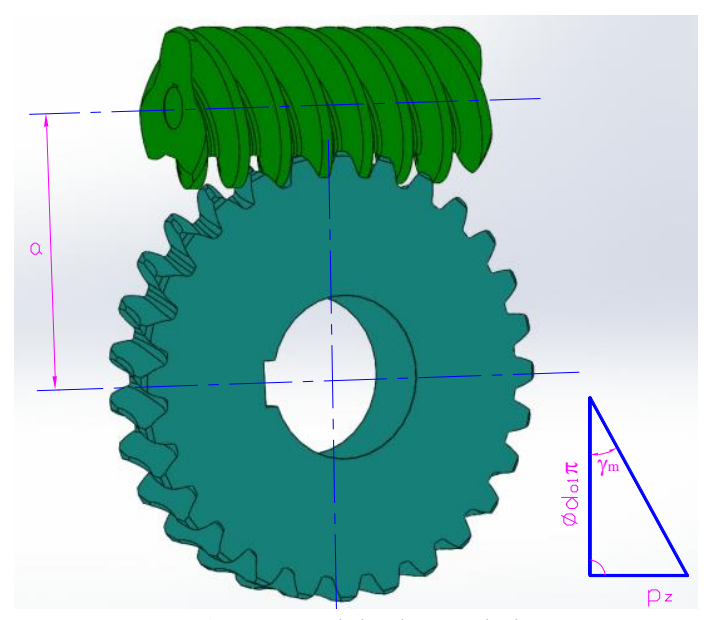

c) assembled model

Figure 2. The geometrical parameters of the worm and the worm wheel

After all the calculations, the CAD models of the elements could be generated by SolidWorks software (Figure 2). The GearTeq and the SolidWorks are interoperable that is why the geometrical parameters of the elements could be imported relatively easily to the SolidWorks for CAD modelling and assembly settings.

\section{ANALYIS OF THE CONTACT SURFACES OF THE WORM WHEEL BY TCA}

Based on the geometrical facts, three worm wheel teeth are connected with the worm at the same time. Each connected teeth are analyzed. The material type of the elements is structural steel [28]. Four coordinate systems are needed for the analysis: 
- one rotational coordinate system for the worm,

- one rotational coordinate system for the worm wheel,

- two coordinate systems for the analyzed tooth connection (linear and normal system).

The axis position of the linear system is the same as that of the rotational system of the worm wheel. The linear- and normal systems are adopted on the middle point of the surface of the worm wheels that we are currently analyzing.

Dense meshing is applied on the analyzed contact area (Figure 3). The dimension of the element is $0.4 \mathrm{~mm}$. Automatic meshing is selected for the outside area. The friction coefficient is $\mu=0.01$ on the contact zone.

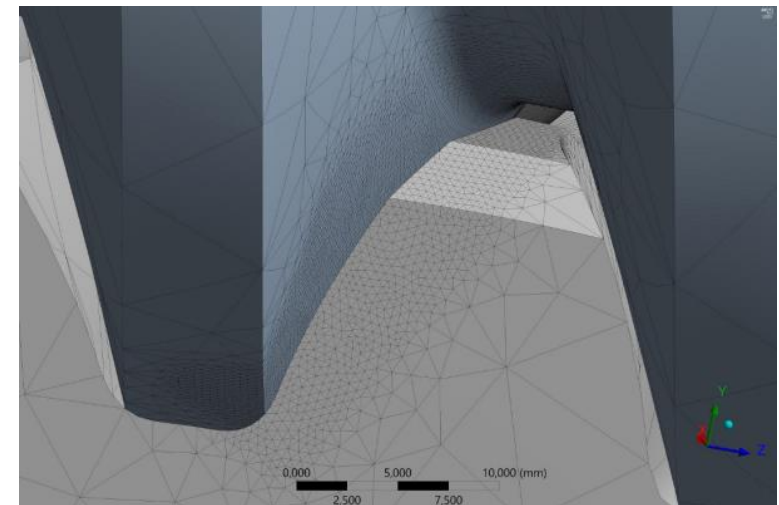

a) meshing

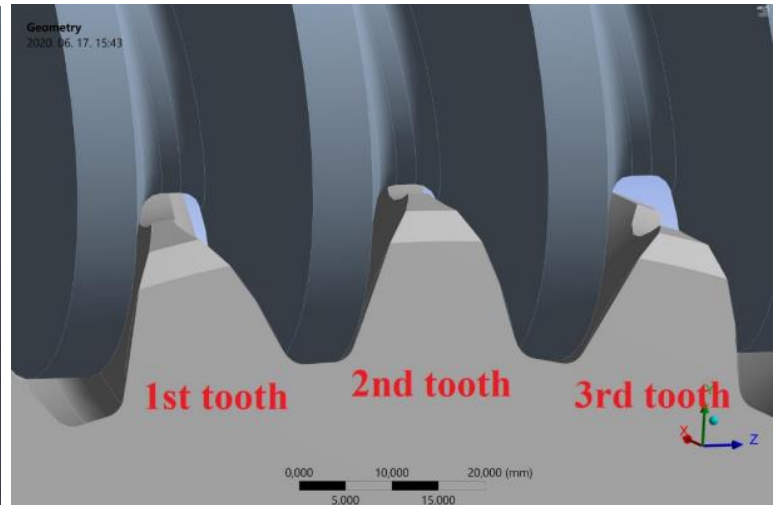

b) the three connected teeth

Figure 3. Tooth connection of the elements

All degrees of freedom are fixed on the worm wheel. Rotation around the axis of rotation of the worm is permitted, other degrees of freedom are also fixed. The worm is loaded by $300 \mathrm{Nm}$ torque around the axis of rotation. The same load is used for every drive.

\subsection{Normal stress analysis}

The normal stress is interpreted perpendicularly to the surface of the worm wheel $[19,28]$. We analyze the average stress results and the geometrical shape of the impressions on the surfaces of the worm wheels for each connected tooth. Figure 4 shows the result of the $1^{\text {st }}$ tooth.

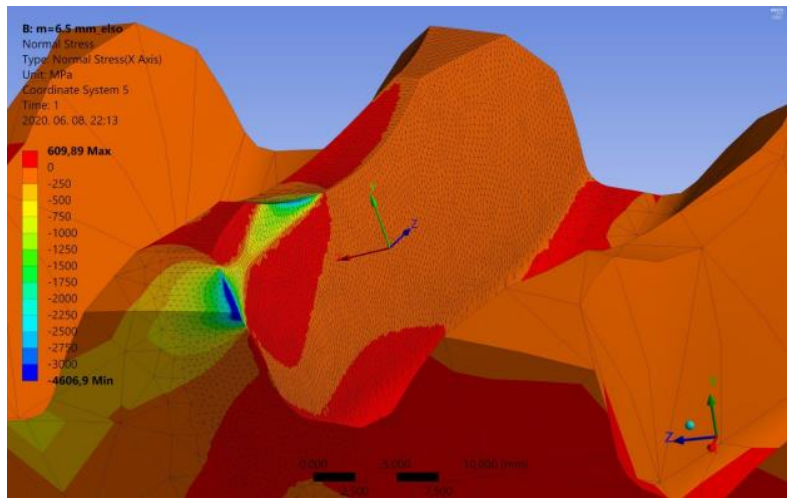

a) $\mathrm{m}=6.5 \mathrm{~mm}$

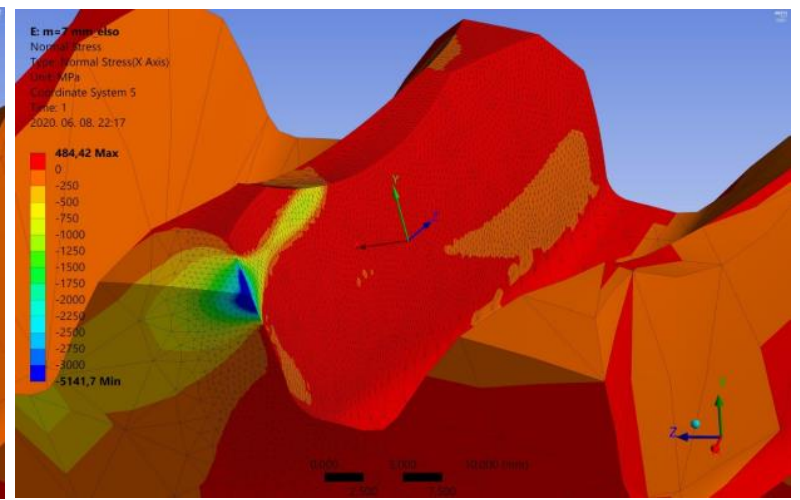

b) $\mathrm{m}=7 \mathrm{~mm}$ 


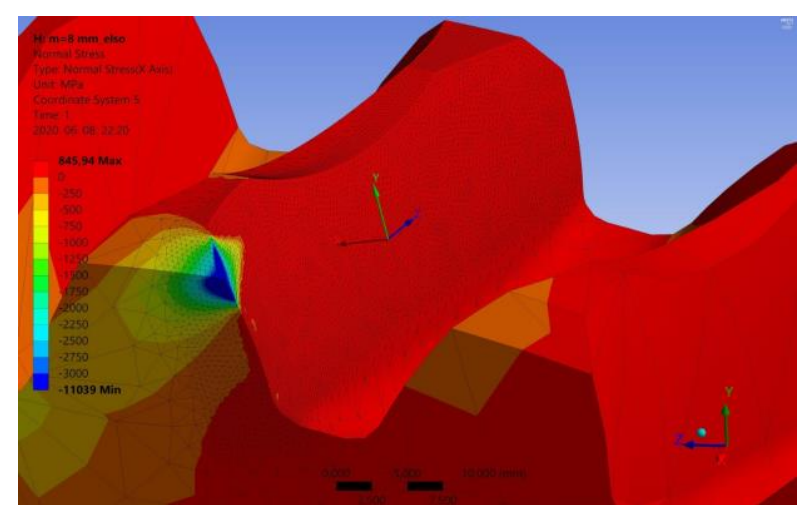

c) $\mathrm{m}=8 \mathrm{~mm}$

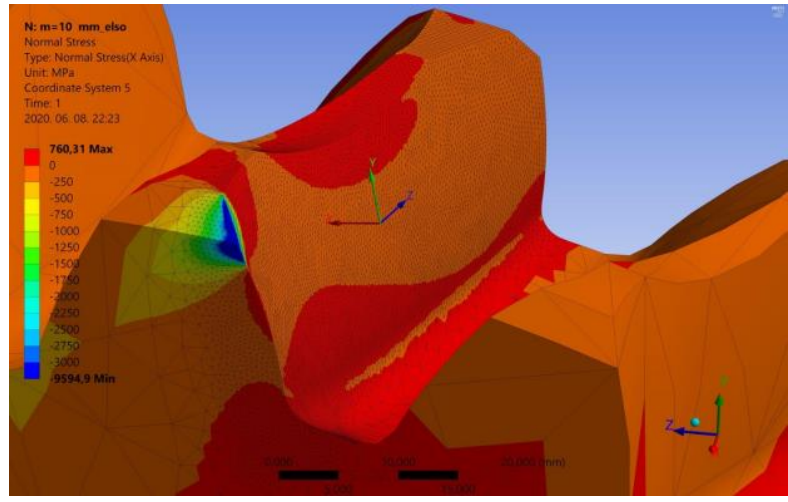

e) $\mathrm{m}=10 \mathrm{~mm}$

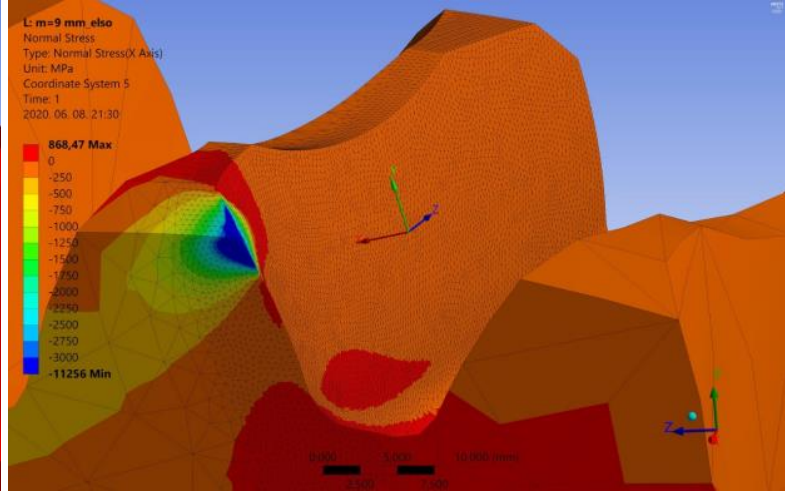

d) $\mathrm{m}=9 \mathrm{~mm}$

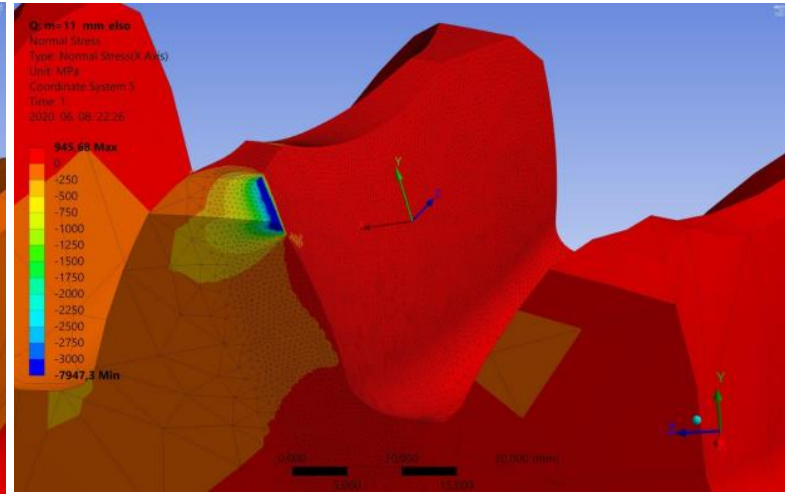

f) $\mathrm{m}=11 \mathrm{~mm}$

Figure 4. Normal stress results on the $1^{\text {st }}$ tooth

The received contact impressions are defined by a lot of peripheral points which are imported to the GeoGebra mathematical software. This software is a complex mathematical software having a lot of operation possibilities. These points are connected by lines. As a result we receive polygons whose area and perimeter could be calculated by mathematical way. Figure 5 shows these polygons.

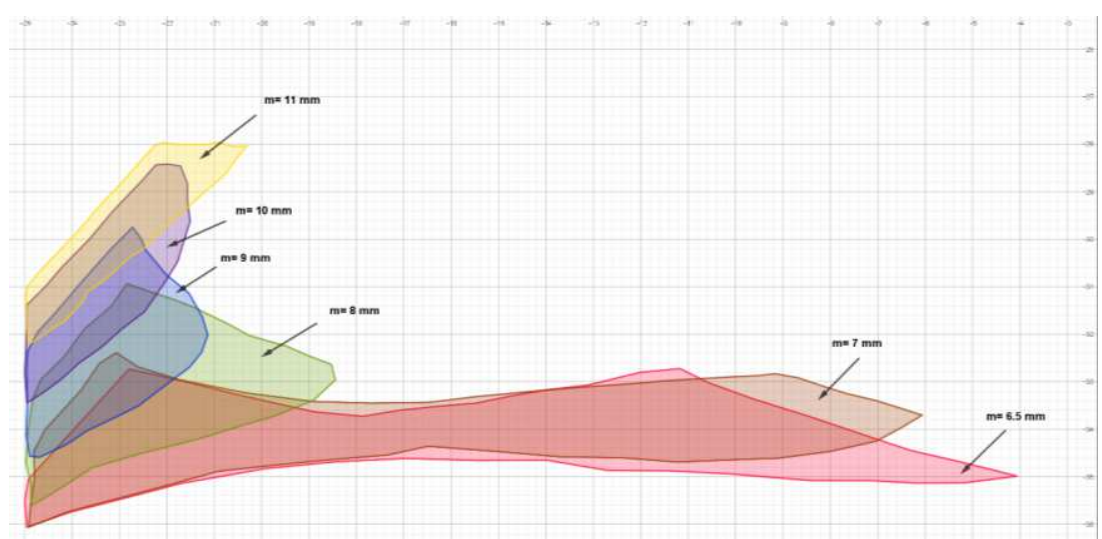

Figure 5. The structure of the stress impressions on the $1^{\text {st }}$ tooth

Figure 6 shows the result of the normal stress on the $2^{\text {nd }}$ tooth while Figure 7 shows the polygons of the impressions. 


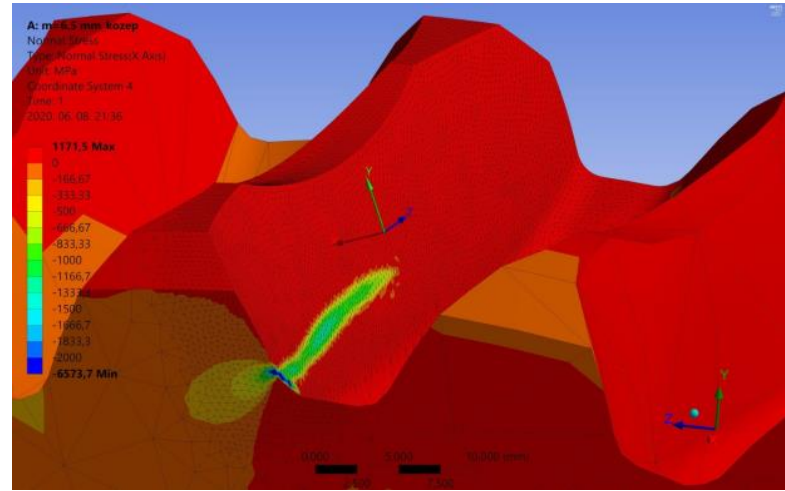

a) $\mathrm{m}=6.5 \mathrm{~mm}$

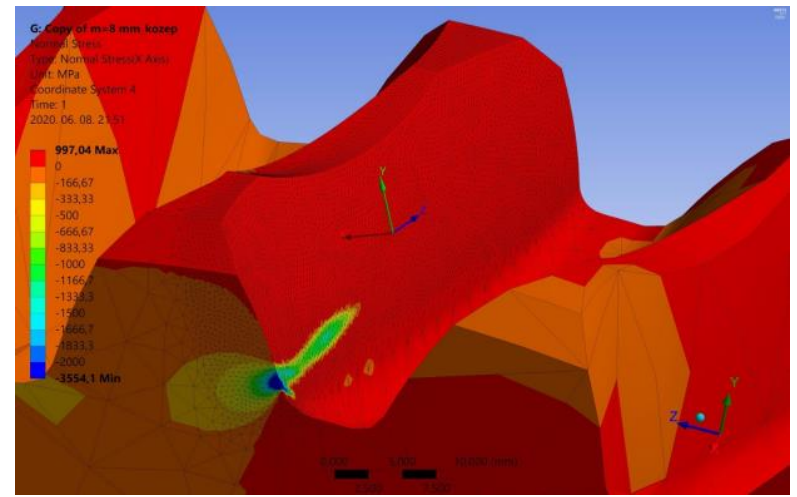

c) $\mathrm{m}=8 \mathrm{~mm}$

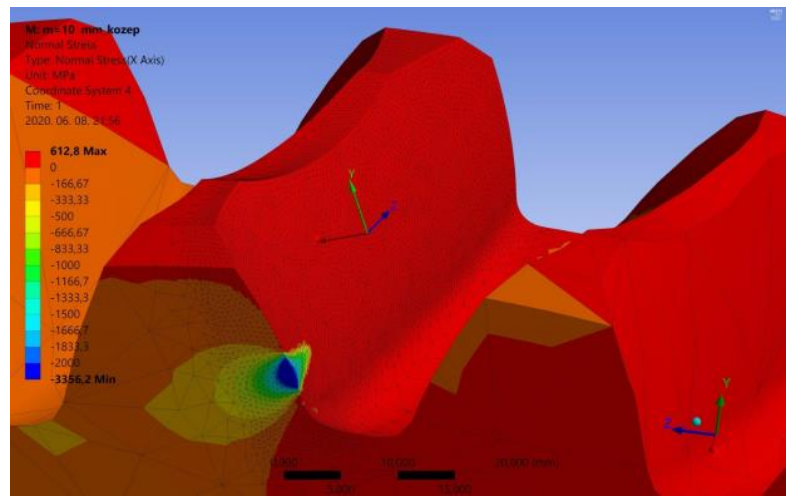

e) $\mathrm{m}=10 \mathrm{~mm}$

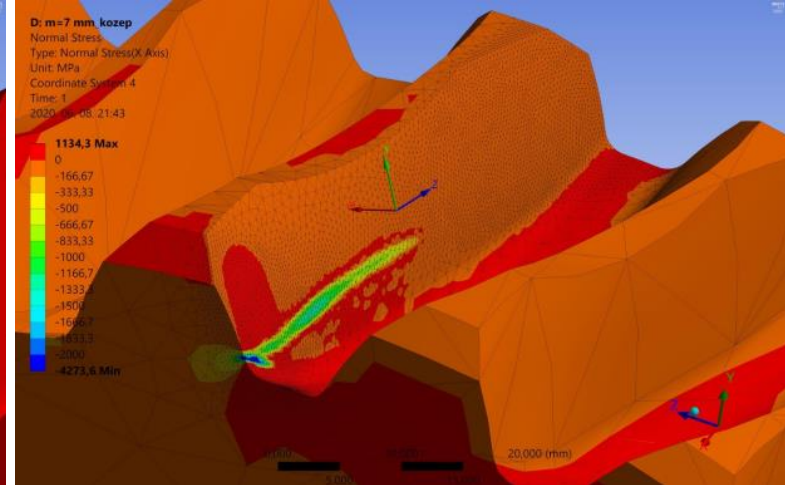

b) $\mathrm{m}=7 \mathrm{~mm}$

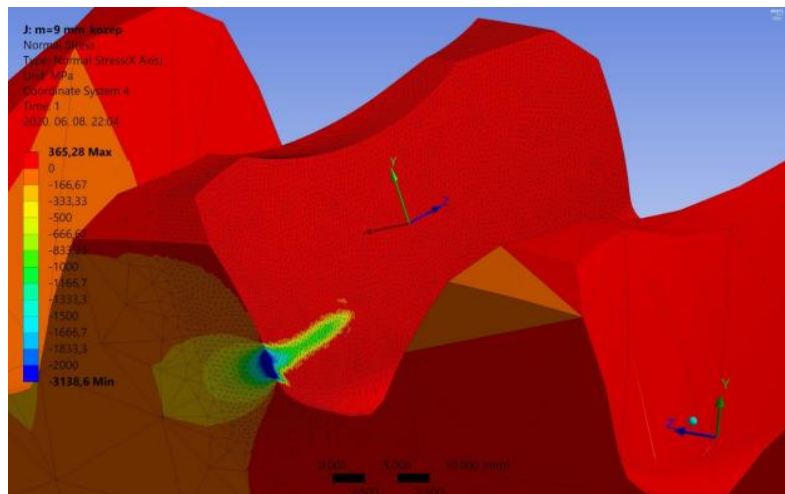

d) $\mathrm{m}=9 \mathrm{~mm}$

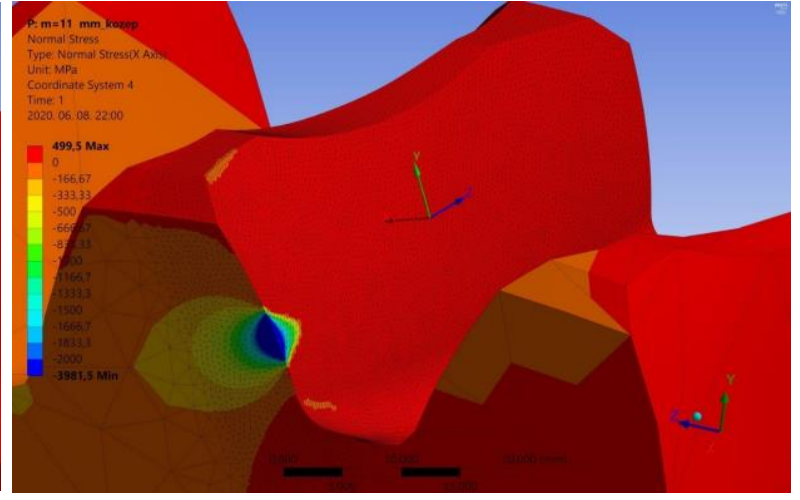

f) $\mathrm{m}=11 \mathrm{~mm}$

Figure 6. Normal stress results on the $2^{\text {nd }}$ tooth

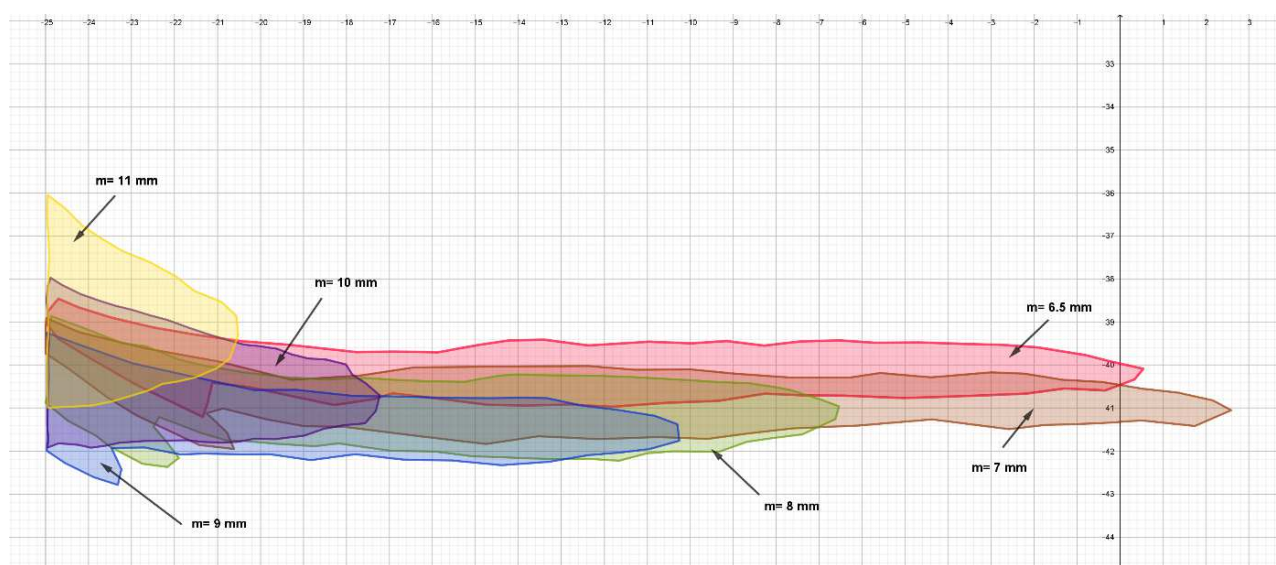

Figure 7. The structure of the stress impressions on the $2^{\text {nd }}$ tooth 


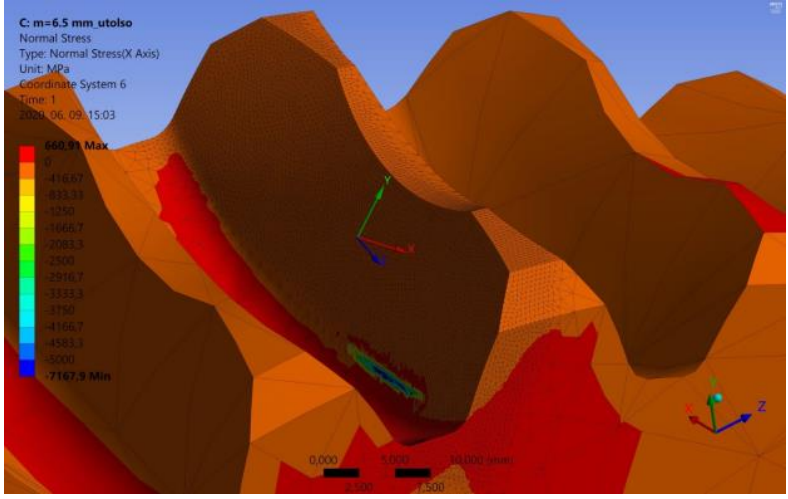

a) $\mathrm{m}=6.5 \mathrm{~mm}$

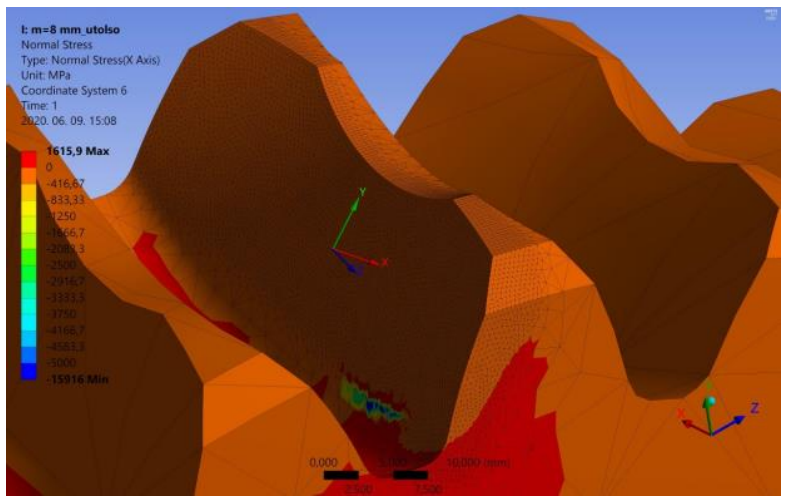

c) $\mathrm{m}=8 \mathrm{~mm}$

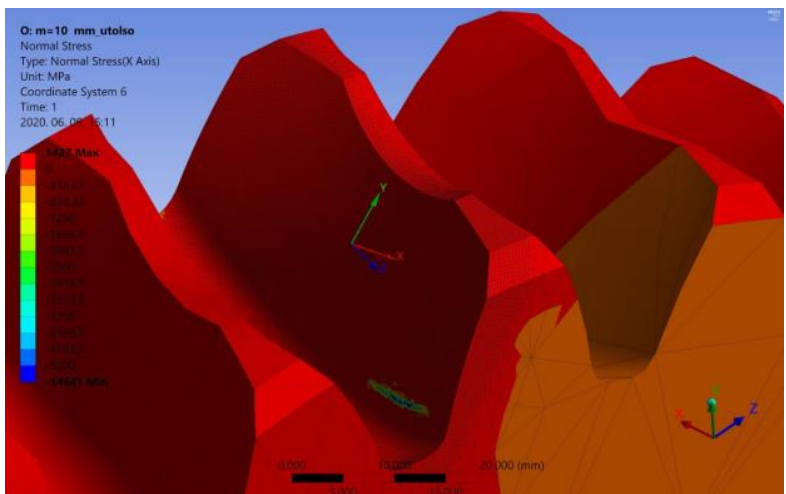

e) $\mathrm{m}=10 \mathrm{~mm}$

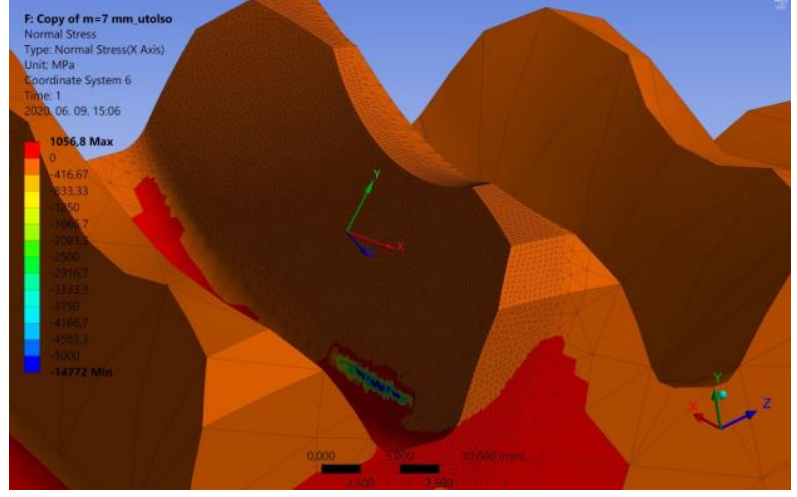

b) $\mathrm{m}=7 \mathrm{~mm}$

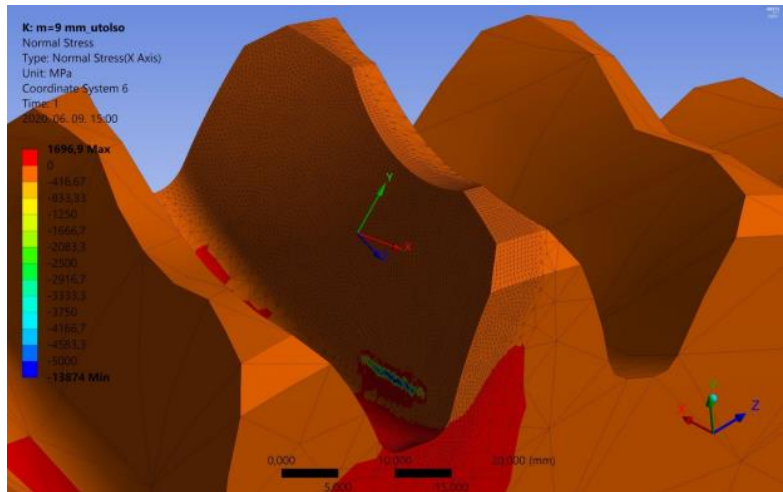

d) $\mathrm{m}=9 \mathrm{~mm}$

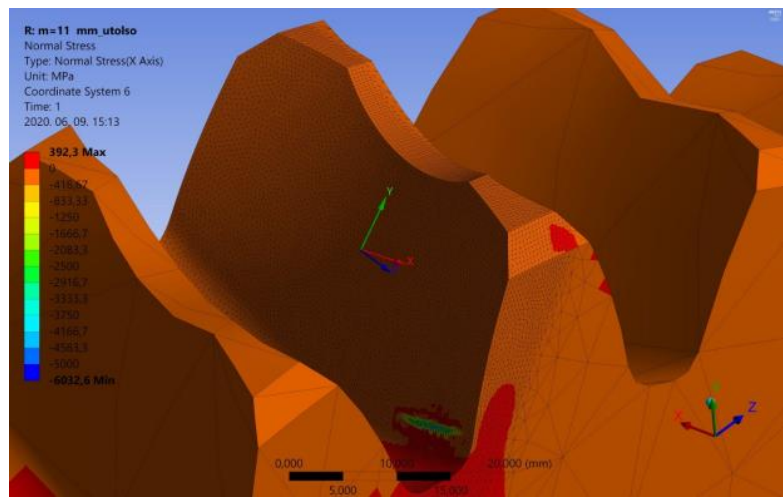

f) $\mathrm{m}=11 \mathrm{~mm}$

Figure 8. Normal stress results on the $3^{\text {rd }}$ tooth

Figure 8 shows the results of normal stress on the $3^{\text {rd }}$ tooth while Figure 9 shows the polygons of the impressions. 


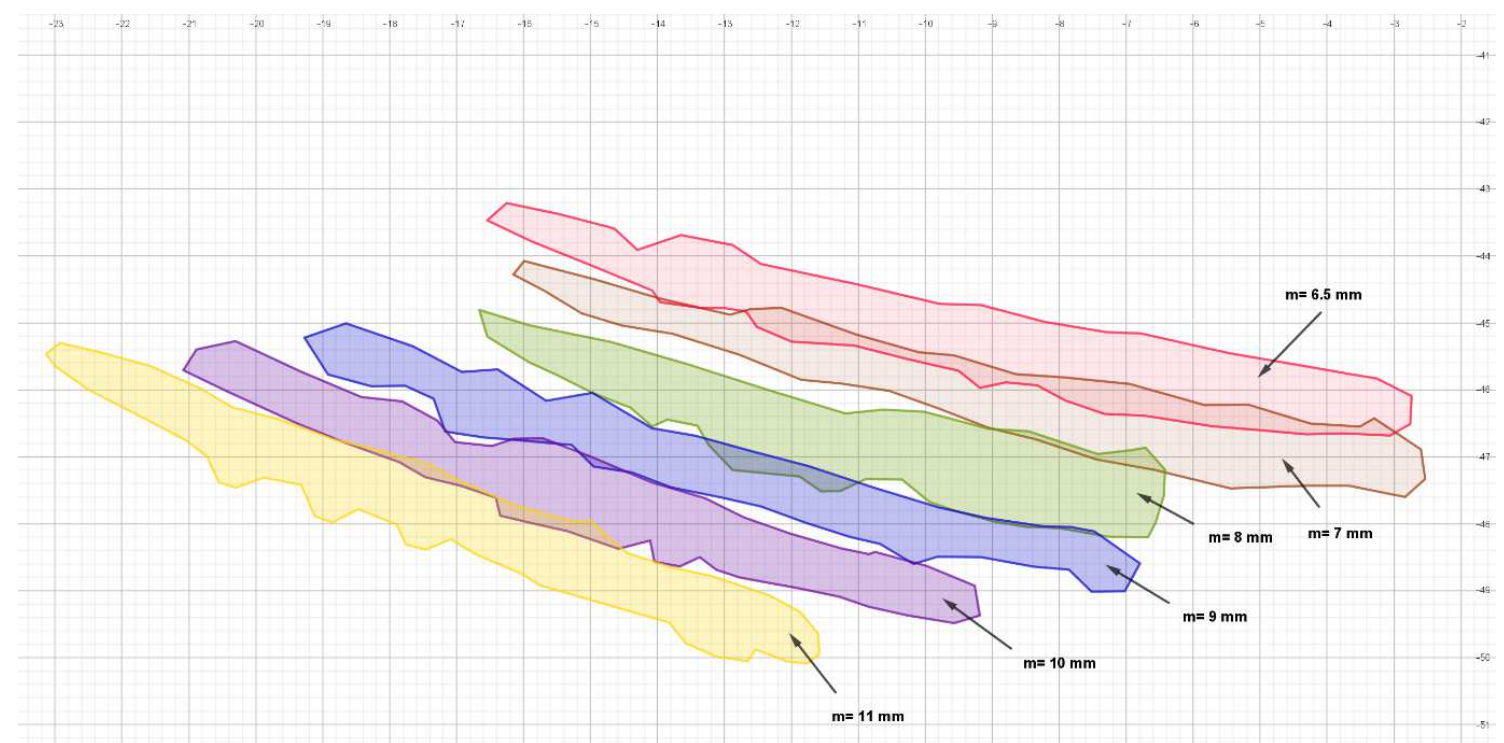

Figure 9. The structure of the stress impressions on the $3^{\text {rd }}$ tooth

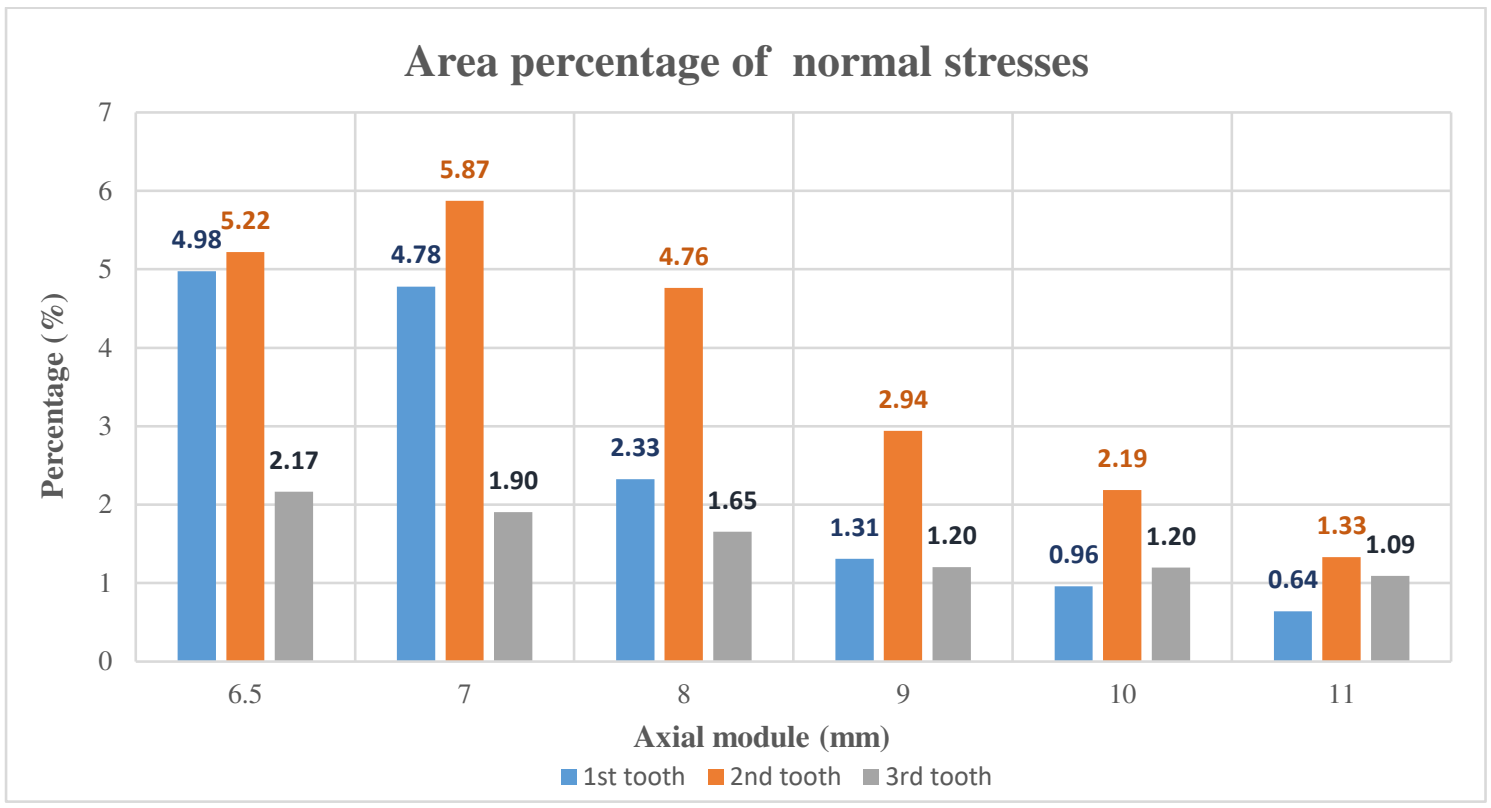

Figure 10. The area percentages of the impressions of the normal stress

The geometrical areas of the surfaces of the worm wheels are determined by polygon method. Figure 10 shows the comparison of the contact impressions and the areas of the surfaces of the worm wheels in percentage. The area percentages are continuously decreasing while there is an increase in the axial module from $\mathrm{m}=7 \mathrm{~mm}$. The highest percentages are on the second tooth since it is totally in contact. The results on the third tooth are the lowest to $\mathrm{m}=9 \mathrm{~mm}$ axial module. After that the results on the $3^{\text {rd }}$ tooth are higher than on the $2^{\text {nd }}$ tooth $(\mathrm{m}=10 \mathrm{~mm}$ and $\mathrm{m}=11 \mathrm{~mm}$ ). Due to the modifications of the modules, the areas and the geometrical shapes of the surfaces of the worm wheels were modified.

Figure 11 shows the perimetrical percentage. The results are constantly decreasing depending on the increase of the axial module. The highest percentages are on the $2^{\text {nd }}$ tooth upto $\mathrm{m}=9 \mathrm{~mm}$ axial module. After that the highest results are on the $3^{\text {rd }}$ teeth. 
The lowest results are on the $3^{\text {rd }}$ tooth upto $\mathrm{m}=7 \mathrm{~mm}$ axial module. After that the lowest results are on the $1^{\text {st }}$ teeth.

Based on Figure 12, the average normal stress results are fluctuating and increasing depending on axial module. The highest results on the $1^{\text {st }}$ and $2^{\text {nd }}$ teeth are always fluctuating depending on the axial module.

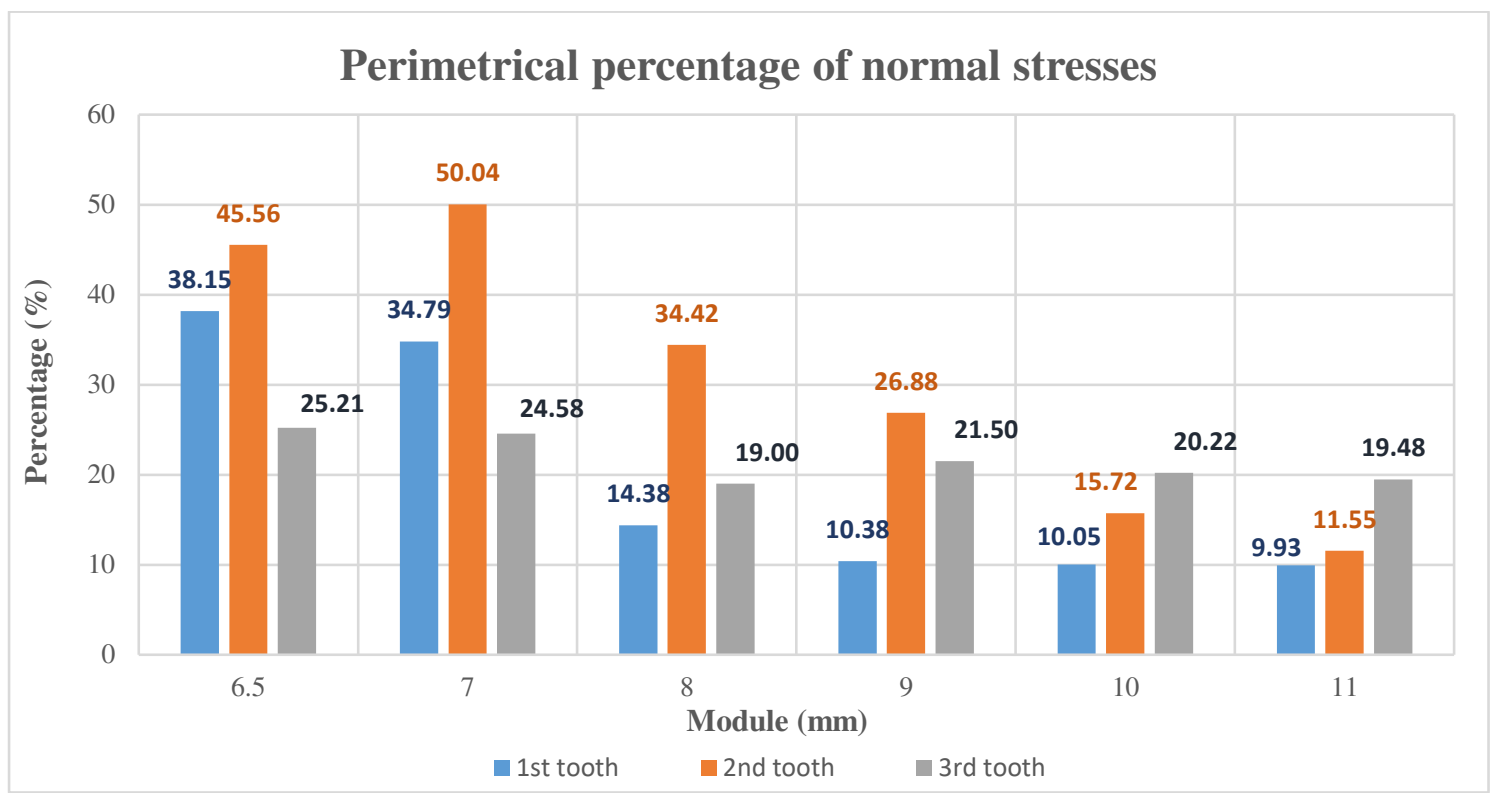

Figure 11. The perimetrical percentages as a result of the normal stress

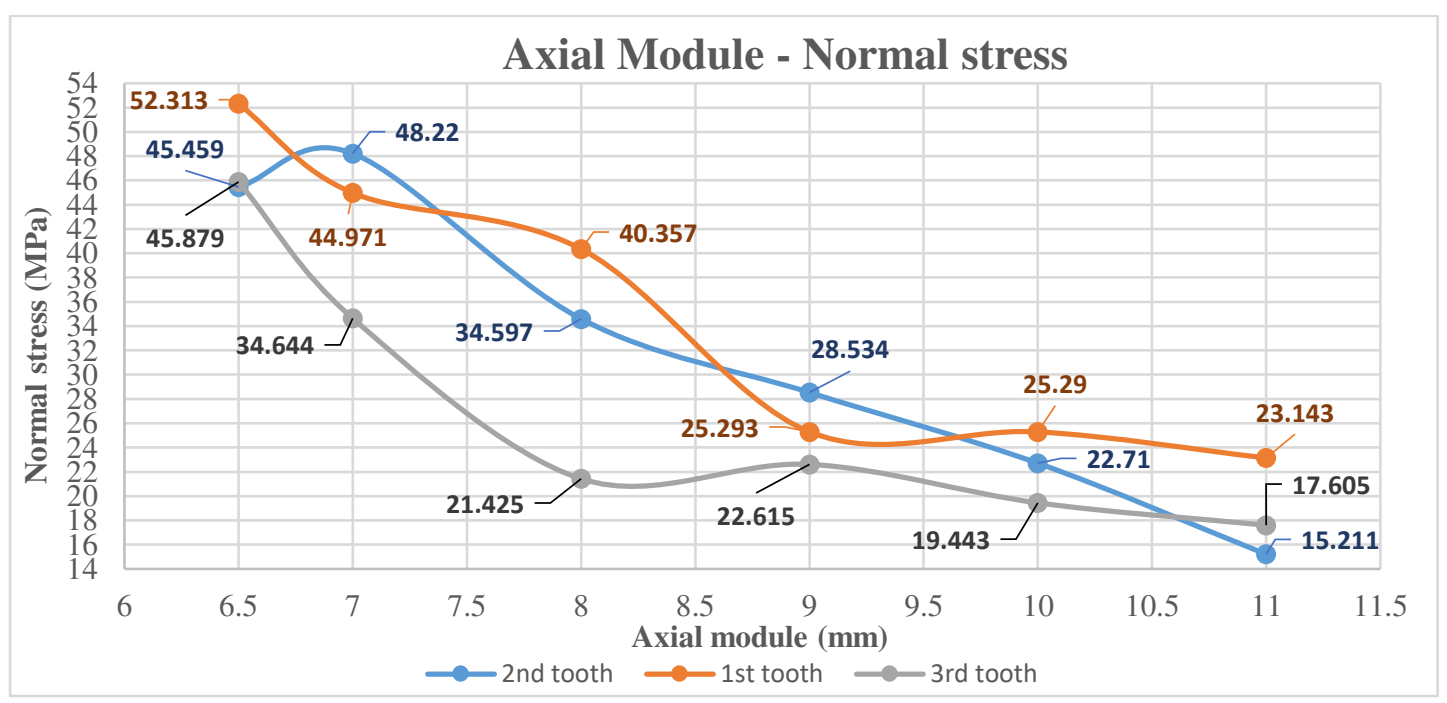

Figure 12. The average normal stress results depending on the axial module

\subsection{Normal deformation analysis}

The normal deformation is analyzed perpendicularly to the surface of the worm wheel [19, 28]. It was also analyzed for each connecting tooth of the worm wheel. 


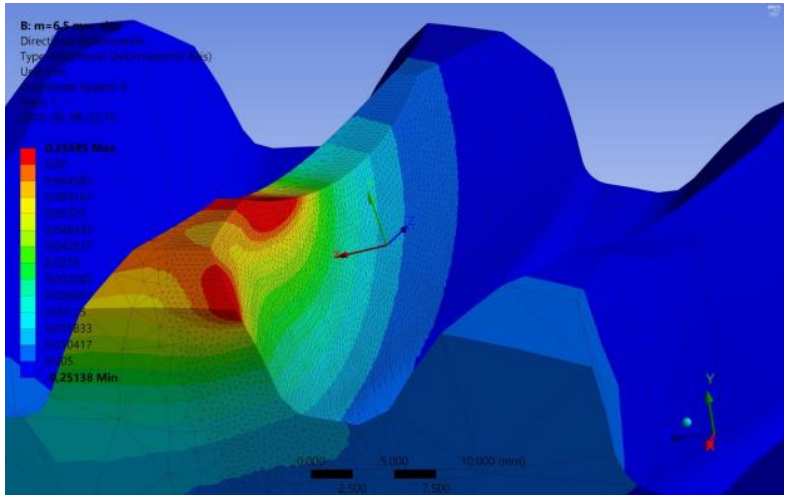

a) $\mathrm{m}=6.5 \mathrm{~mm}$

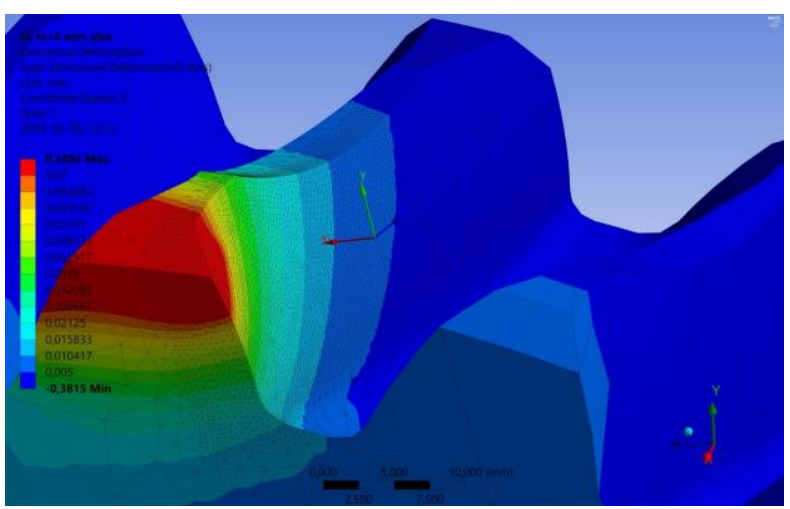

c) $\mathrm{m}=8 \mathrm{~mm}$

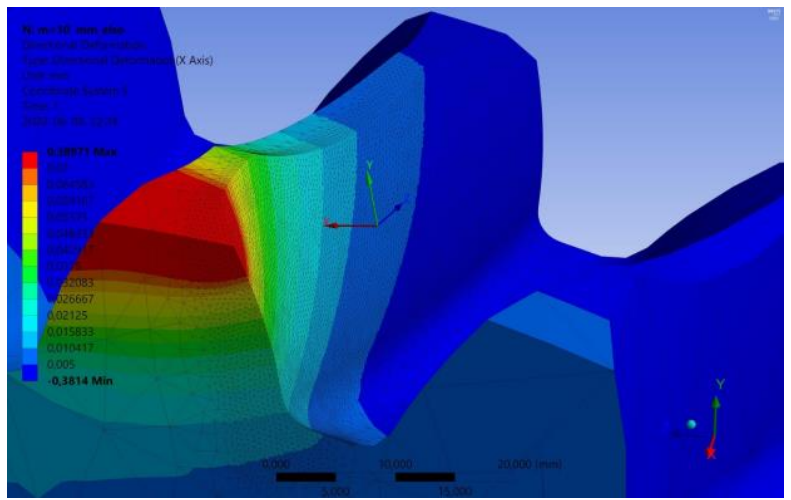

e) $\mathrm{m}=10 \mathrm{~mm}$

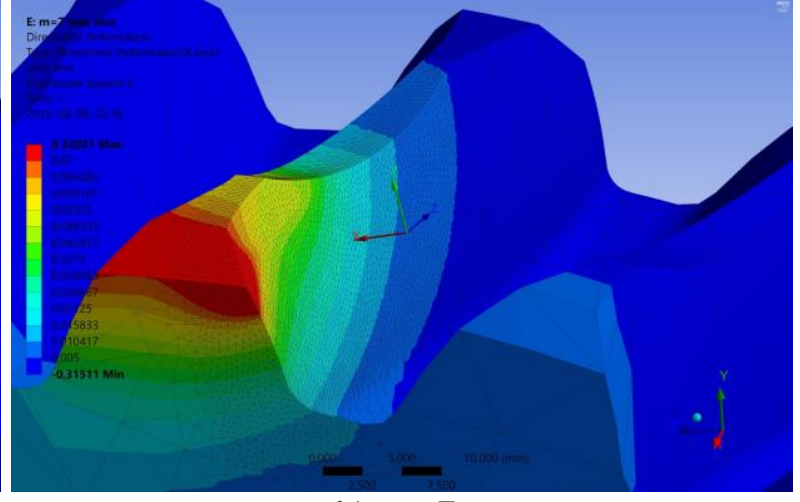

b) $\mathrm{m}=7 \mathrm{~mm}$

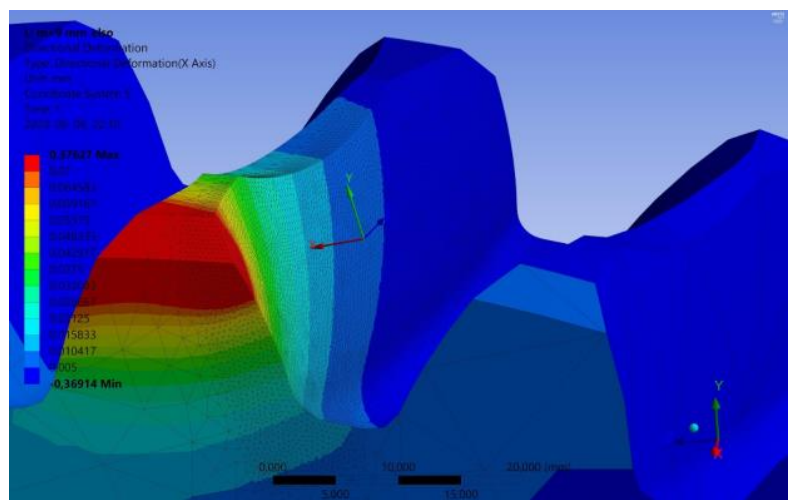

d) $\mathrm{m}=9 \mathrm{~mm}$

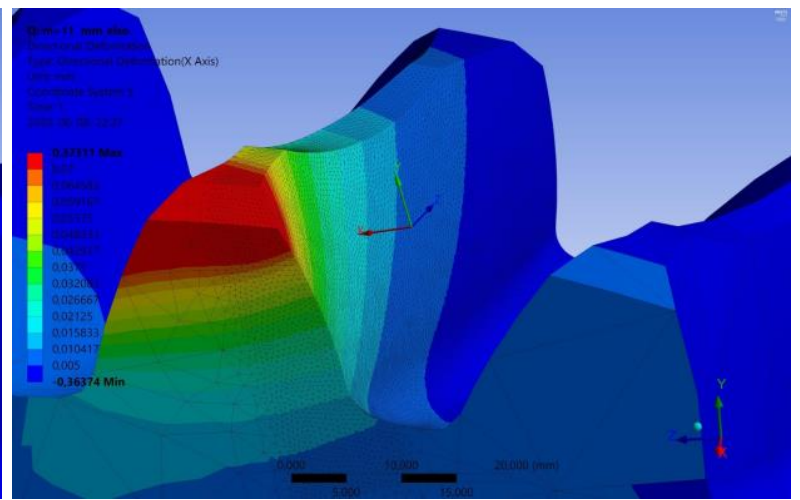

f) $\mathrm{m}=11 \mathrm{~mm}$

Figure 13. Results of normal deformation on the $1^{\text {st }}$ tooth

The effects of the deformation zones are saved into the GeoGebra software. We set lines to the shape of the zones which connect the border points of the deformation zones (Polygon method). Similarly to the stress analyses, we receive polygons, of which area and perimeter could be calculated by mathematical way. Figure 13 and 14 show the results in case of the $1^{\text {st }}$ tooth. 


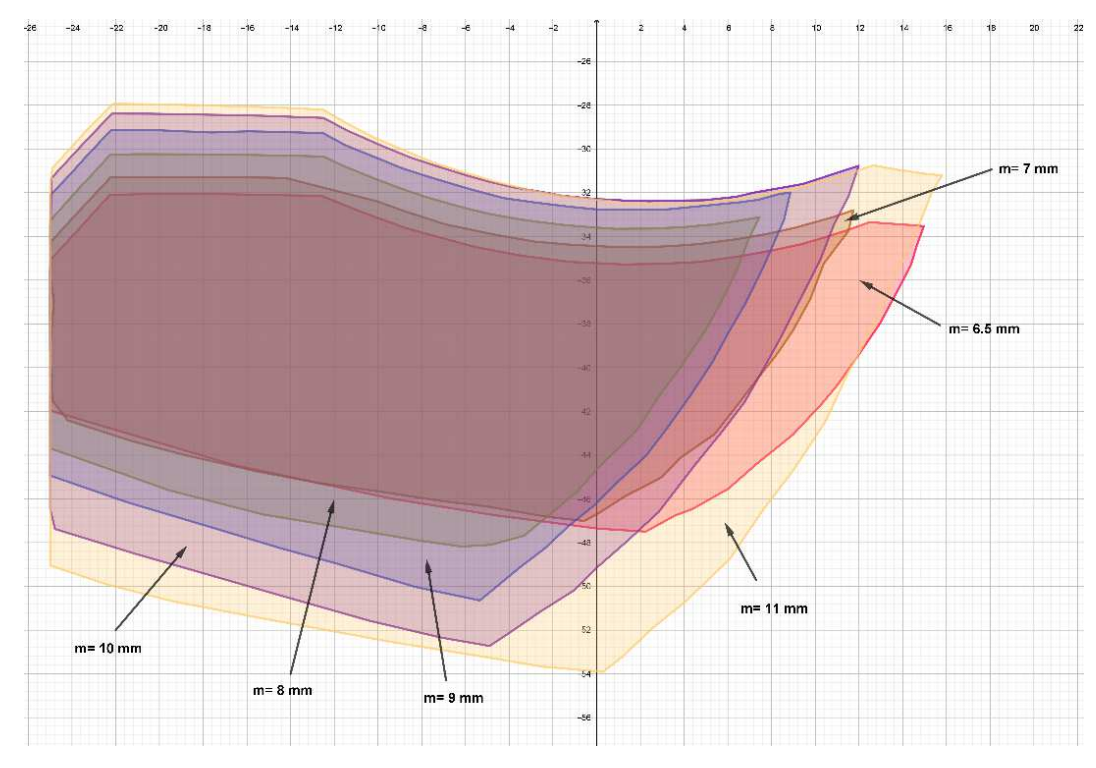

Figure 14. The resulted structure of deformation in case of the $1^{\text {st }}$ tooth

Figure 15 shows the result of the normal deformation on the $2^{\text {nd }}$ tooth. Figure 16 shows the resulted polygons of the deformation zones.

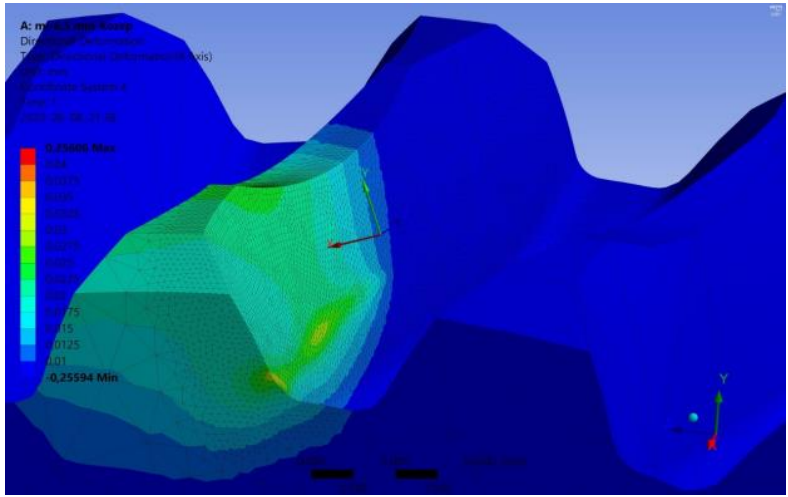

a) $\mathrm{m}=6.5 \mathrm{~mm}$

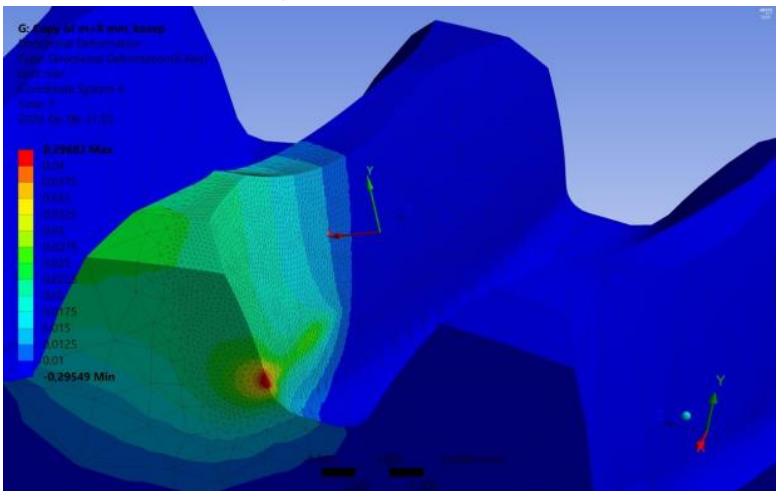

c) $\mathrm{m}=8 \mathrm{~mm}$

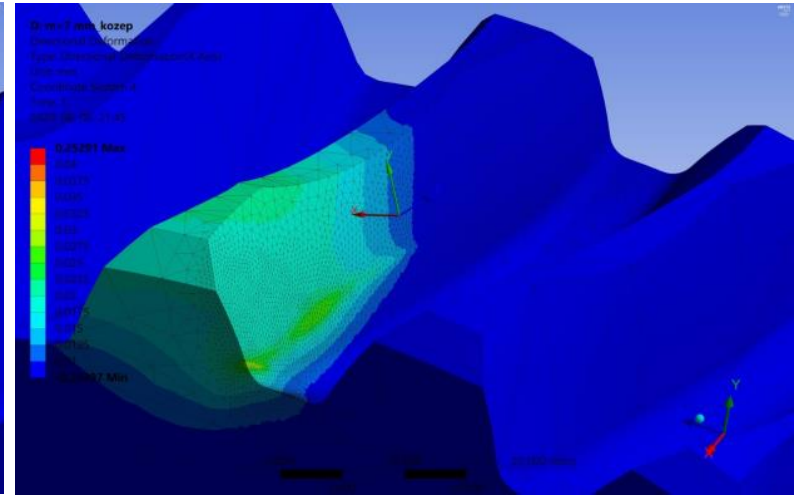

b) $\mathrm{m}=7 \mathrm{~mm}$

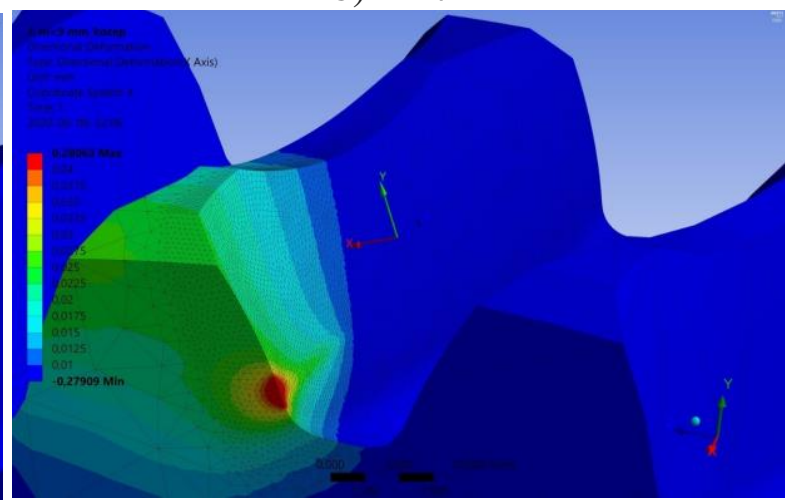

d) $\mathrm{m}=9 \mathrm{~mm}$ 


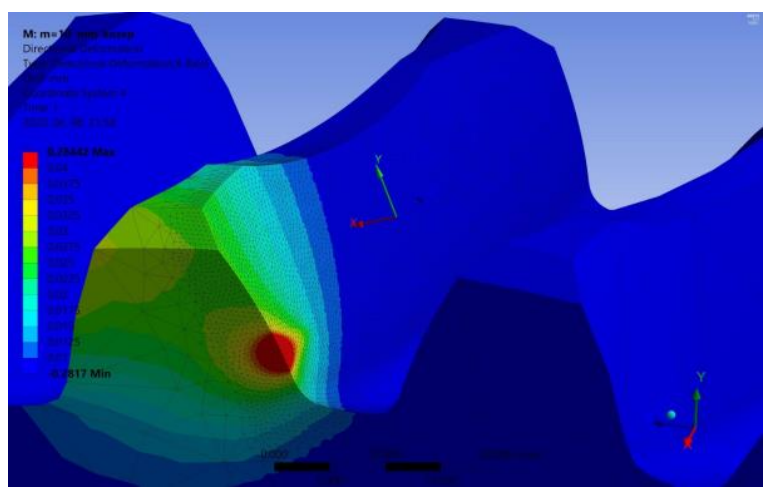

e) $\mathrm{m}=10 \mathrm{~mm}$

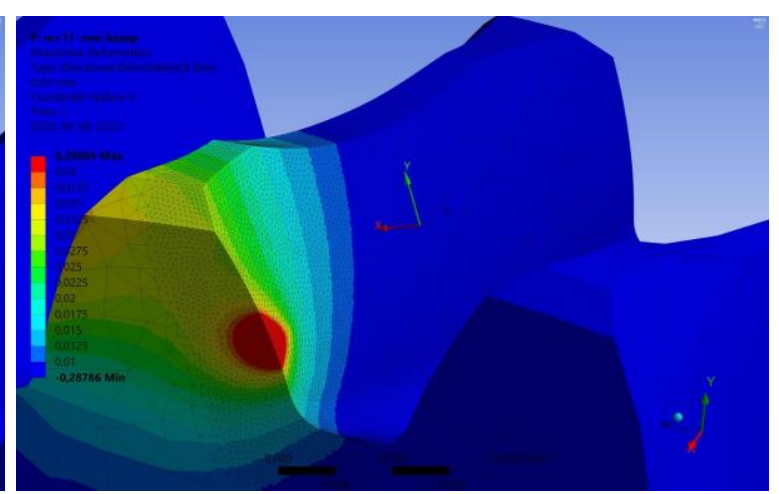

f) $\mathrm{m}=11 \mathrm{~mm}$

Figure 15. Results of normal deformation in case of the $2^{\text {nd }}$ tooth

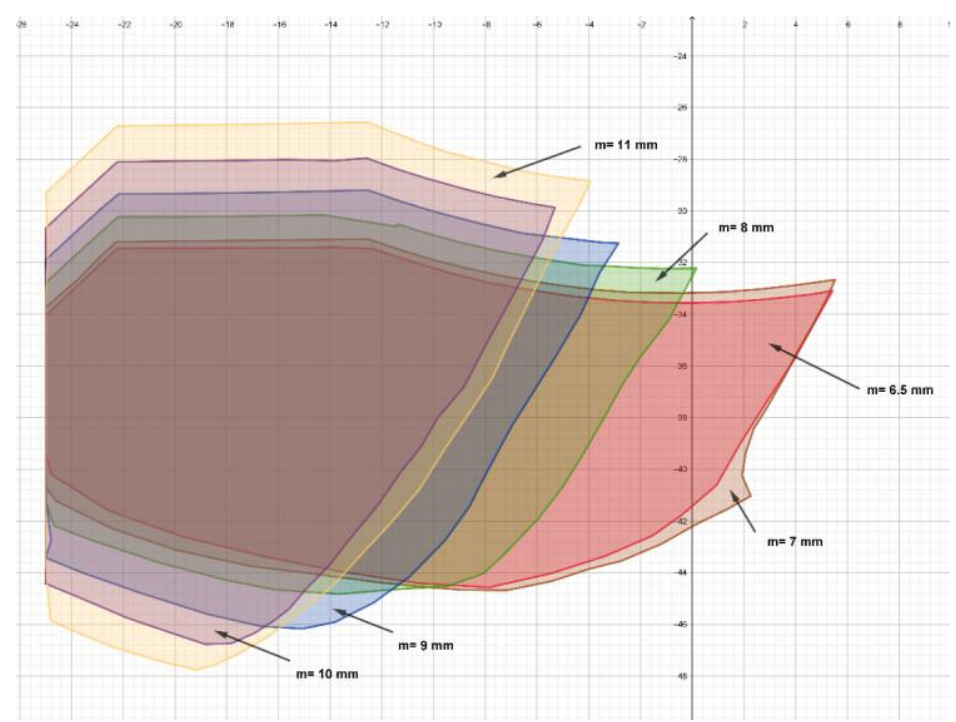

Figure 16. The resulted structure of deformation in case of the $2^{\text {nd }}$ tooth

Figure 17 shows the result of normal deformation on the $3^{\text {rd }}$ tooth. Figure 18 shows the resulted polygons of the deformation zones.

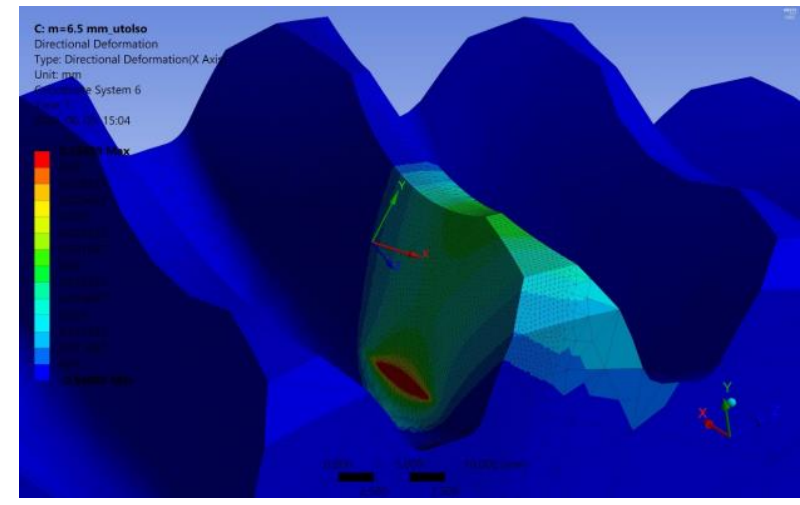

a) $\mathrm{m}=6.5 \mathrm{~mm}$

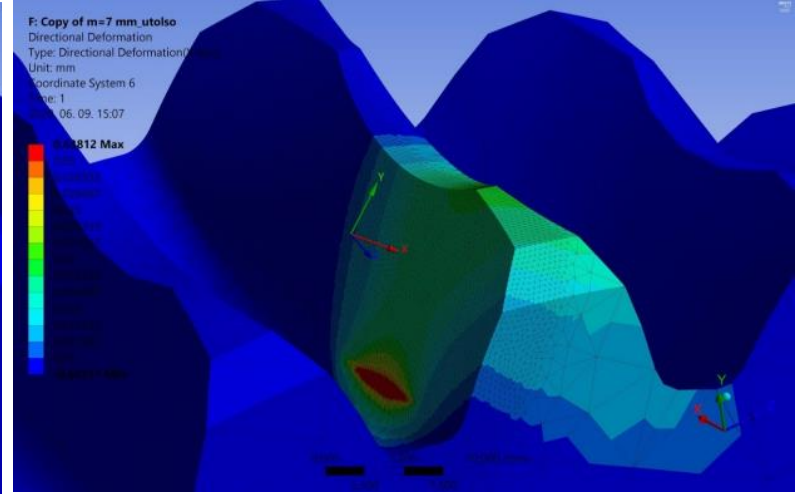

b) $\mathrm{m}=7 \mathrm{~mm}$ 


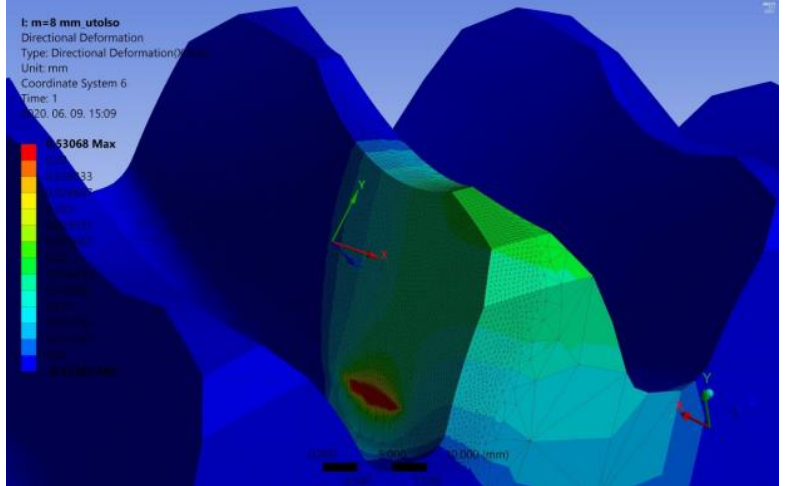

c) $\mathrm{m}=8 \mathrm{~mm}$

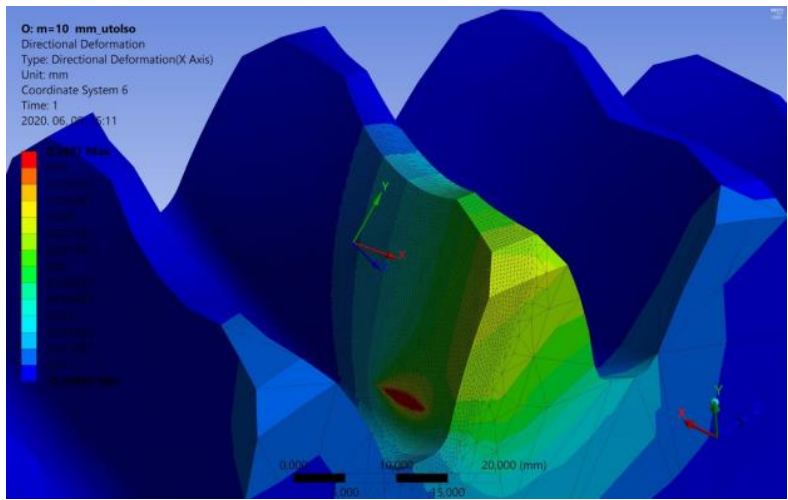

e) $\mathrm{m}=10 \mathrm{~mm}$

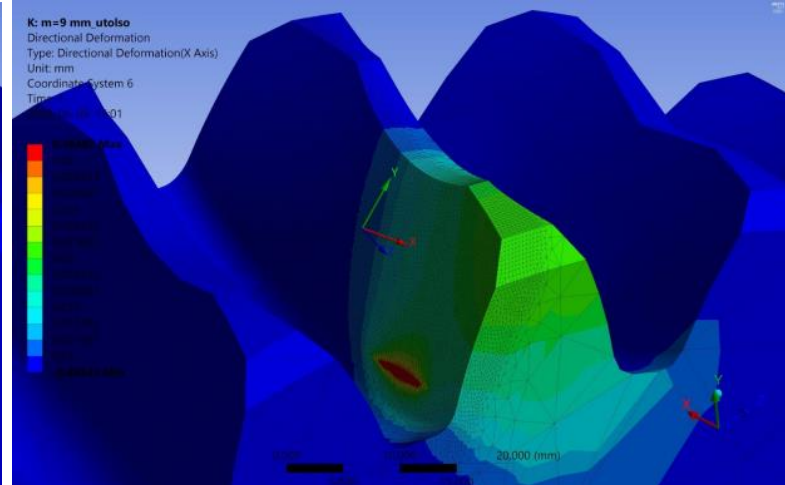

d) $\mathrm{m}=9 \mathrm{~mm}$

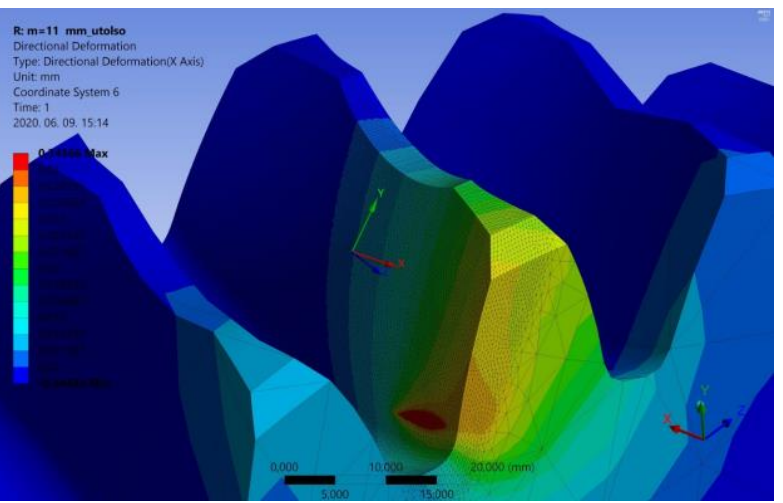

f) $\mathrm{m}=11 \mathrm{~mm}$

Figure 17. Results of normal deformation in case of the $3^{\text {rd }}$ tooth

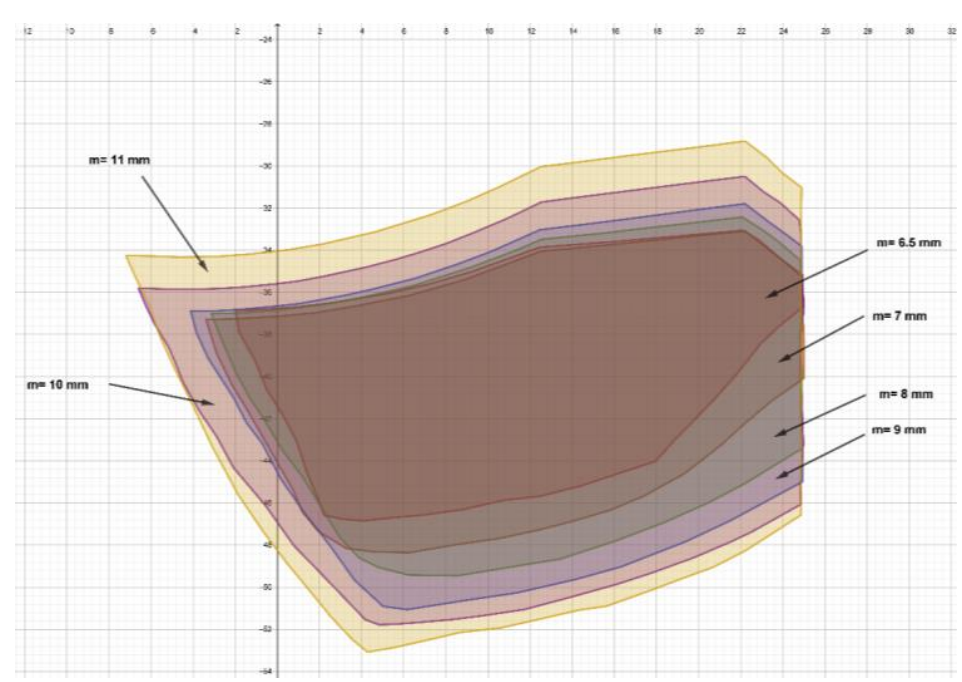

Figure 18. The structure of deformation impressions on the $3^{\text {rd }}$ teeth

With the knowledge of the resulted areas due to normal deformation and the whole surfaces of the teeth of the worm wheels, the area percentages could be determined (Figure 19). The highest results are received on the $1^{\text {st }}$ tooth due to the maximum loads. This result decreases up to $m=8$ mm axial module. After that, it starts increasing.

The result on the $2^{\text {nd }}$ and $3^{\text {rd }}$ teeth are continuously fluctuating depending on the axial module. 
The area percentage of the $\mathrm{m}=6.5 \mathrm{~mm}$ and $\mathrm{m}=7 \mathrm{~mm}$ axial module are higher on the $2^{\text {nd }}$ tooth than on the $3^{\text {rd }}$ tooth. After that, the results on the $3^{\text {rd }}$ tooth are the $2^{\text {nd }}$ highest.

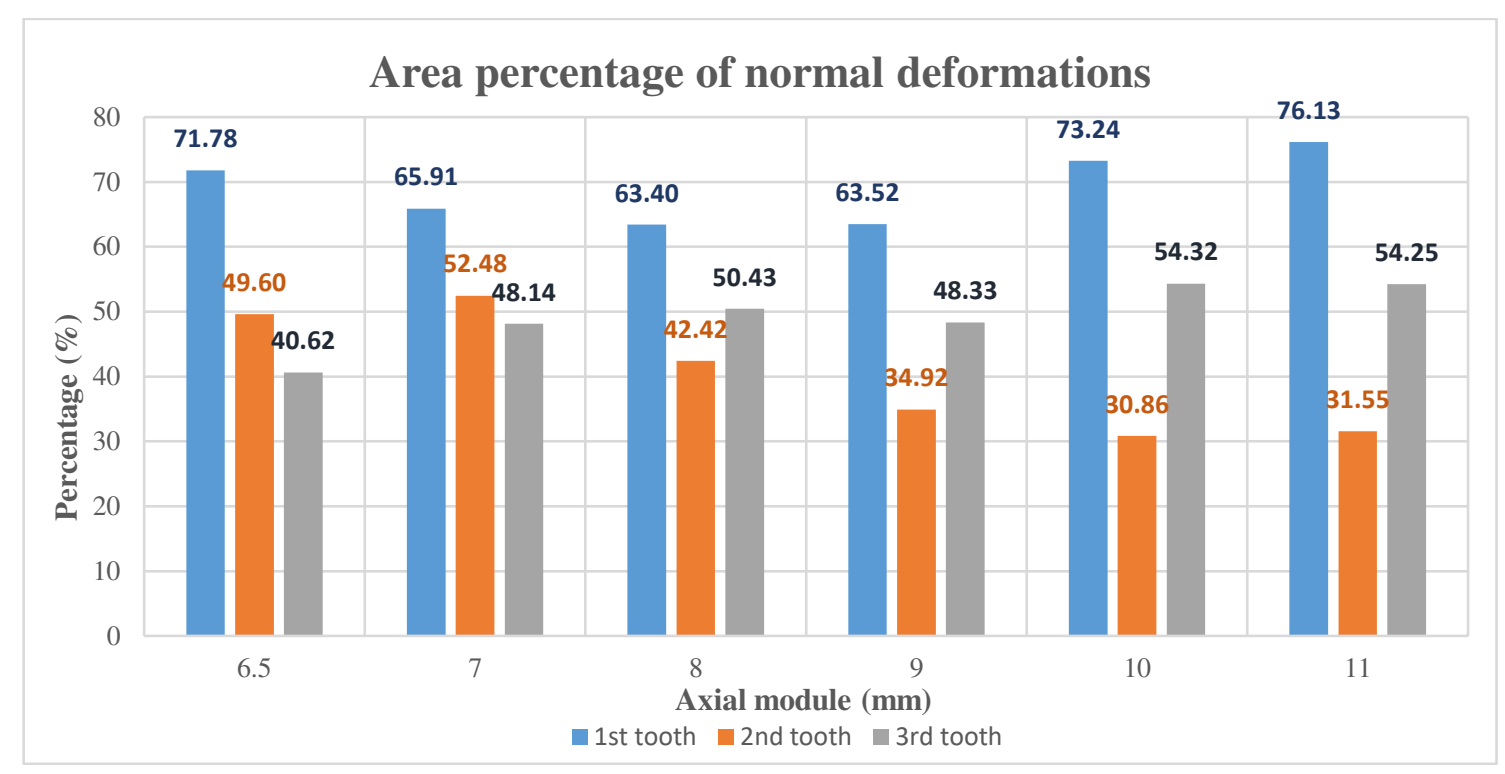

Figure 19. The resulted area percentages due to normal deformation

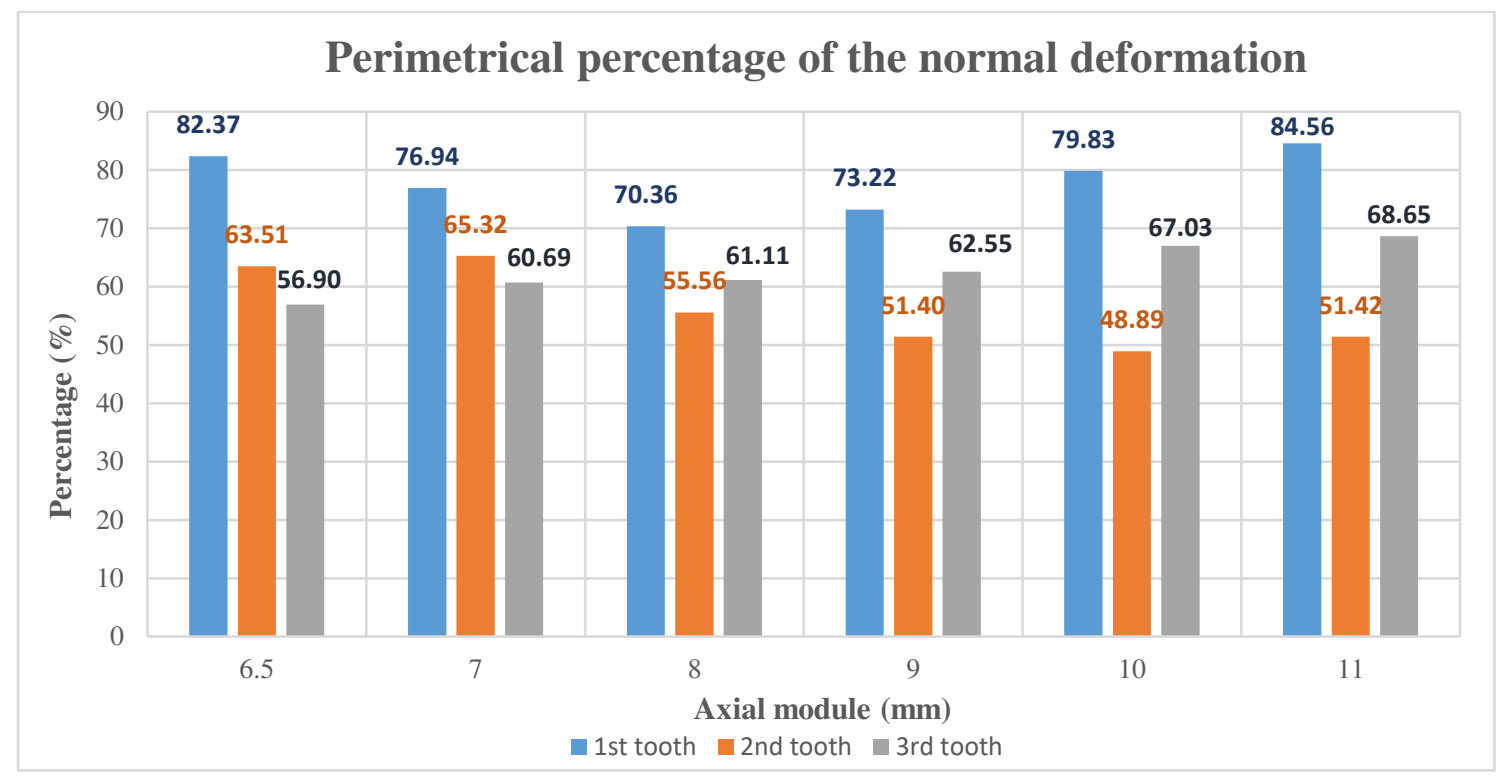

Figure 20. The resulted perimetrical percentages due to normal deformation

Figure 20 shows the perimetrical percentages between the impressions of the normal deformations and the whole surfaces of the worm wheels. The highest results are on the $1^{\text {st }}$ tooth which decreases up to $\mathrm{m}=8 \mathrm{~mm}$ axial module. After that, it starts increasing.

The perimetrical percentages of the $m=6.5 \mathrm{~mm}$ and $\mathrm{m}=7 \mathrm{~mm}$ axial module are higher on the $2^{\text {nd }}$ tooth than on the $3^{\text {rd }}$ tooth. After that, the results on the third tooth are the second highest. The results on the $2^{\text {nd }}$ tooth are continuously fluctuating depending on the axial module. The results on the $3^{\text {rd }}$ tooth are increasing depending on the axial module. 


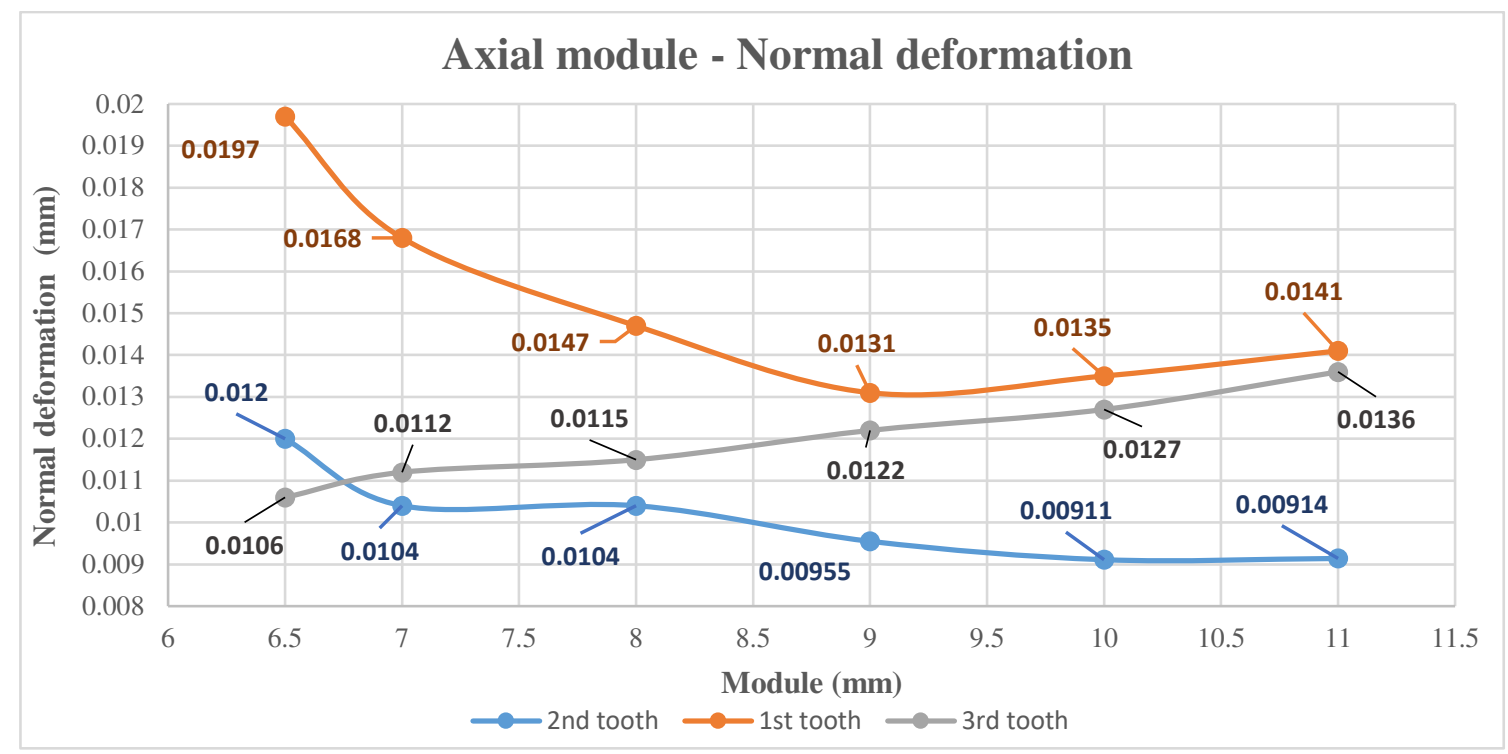

Figure 21. The average result due to normal deformation depending on the axial module

The average normal deformation values are also calculated (Figure 21). The highest results are received on the $1^{\text {st }}$ tooth which decrease up to $\mathrm{m}=9 \mathrm{~mm}$ axial module. After that, it starts increasing. The highest result on the $1^{\text {st }}$ tooth is in case of $\mathrm{m}=6.5 \mathrm{~mm}$ axial module.

The results on the $2^{\text {nd }}$ tooth is fluctuating and continuously increasing. It is lower than the results on the $3^{\text {rd }}$ tooth except in case of $\mathrm{m}=6.5$ axial module.

The results on the $3^{\text {rd }}$ tooth are continuously increasing depending on the axial module but it is always lower than the results on the $1^{\text {st }}$ tooth.

\subsection{Axial- and radial deformation analysis}

The average deformations on the connecting teeth are also determined and divided into axial and radial directions on the surfaces of the worm wheels (Figure 22 and 23).

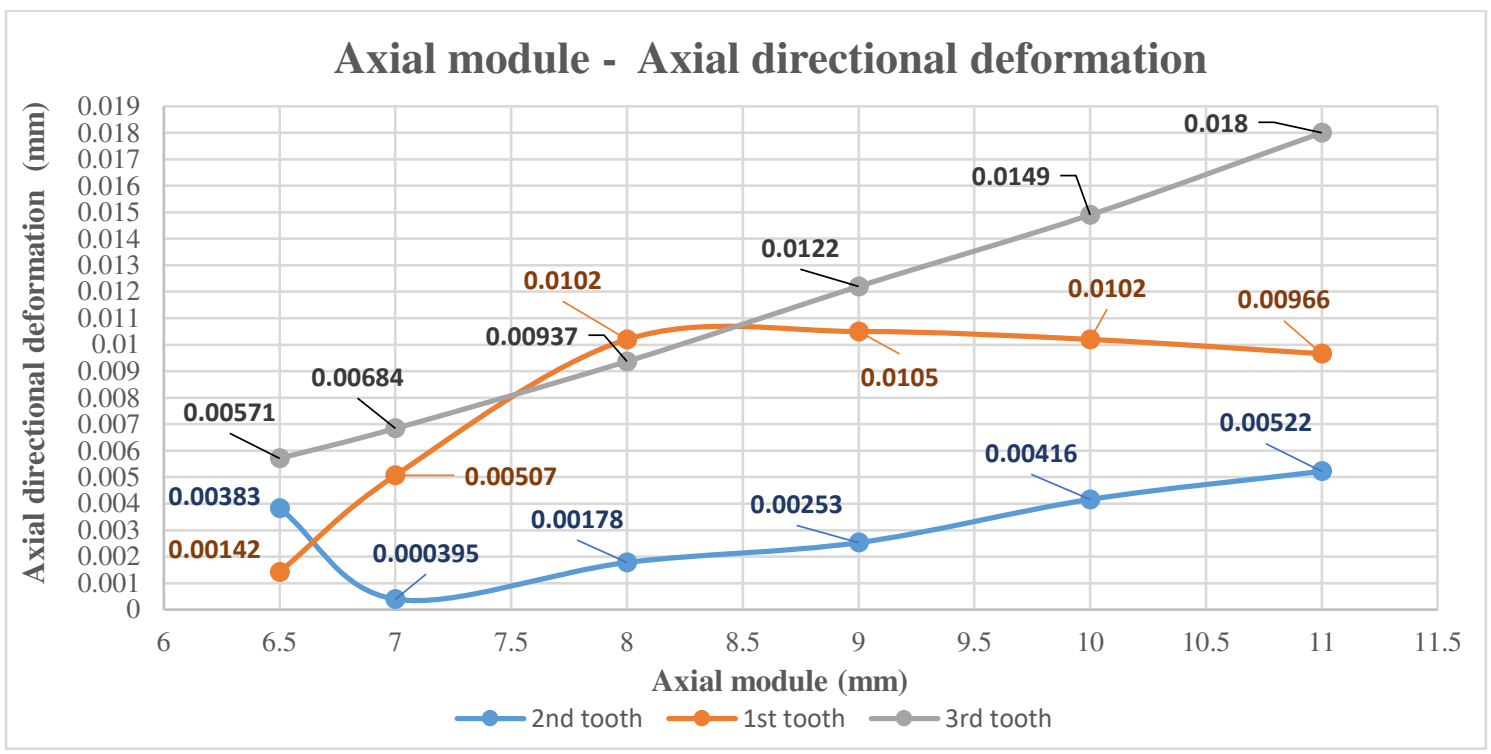

Figure 22. Axial module -deformation diagram in axial direction

Based on Figure 22, the following statements could be defined: 
- the lowest results are on the $2^{\text {nd }}$ tooth. It is continuously increasing from $\mathrm{m}=7 \mathrm{~mm}$ axial module.

- the results on the $1^{\text {st }}$ tooth are increasing up to $\mathrm{m}=8 \mathrm{~mm}$ axial module. After that, they are decreasing. The highest result is in case of $\mathrm{m}=8 \mathrm{~mm}$ axial module.

- the results on the $3^{\text {rd }}$ tooth are continuously increasing depending on the axial module.

- the results on the $3^{\text {rd }}$ tooth are always higher than on the $2^{\text {nd }}$ tooth.

Based on Figure 23, the following statements could be defined:

- the highest results are on the $1^{\text {st }}$ tooth. This function is fluctuating. The highest result is in case of $\mathrm{m}=6.5 \mathrm{~mm}$ axial module.

- the results of the $2^{\text {nd }}$ tooth are also fluctuating. The highest results are in case of $m=6.5$ mm axial module.

- the results of the $3^{\text {rd }}$ tooth are continuously decreasing from $\mathrm{m}=7 \mathrm{~mm}$ axial module.

- the lowest results are on the $3^{\text {rd }}$ tooth.

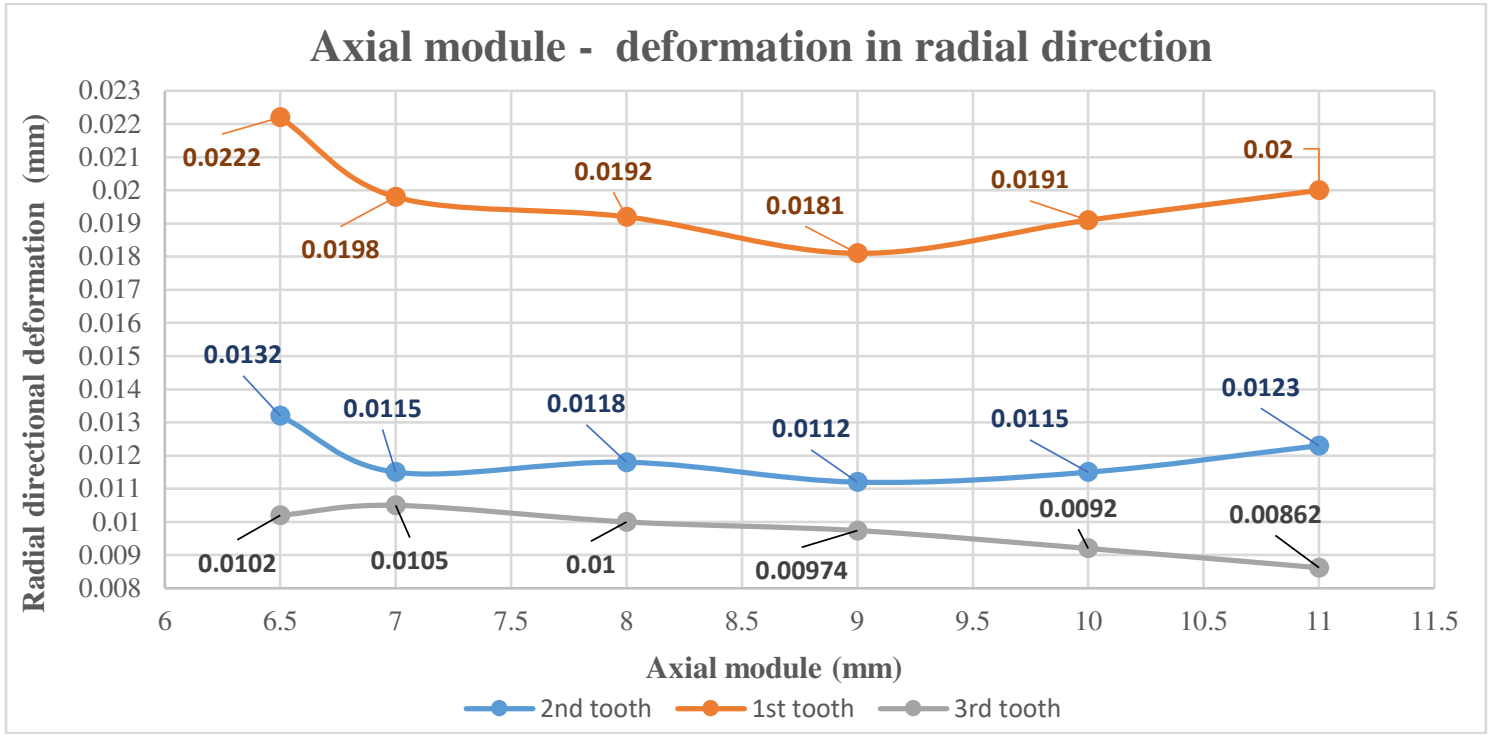

Figure 23. Axial module-deformation diagram in radial direction

\section{CONCLUSION}

The main property of the Archimedean worm is the linear profile which is generated on the axial section of the worm by straight-lined blade. This geometry is widely used for different gear boxes providing good load transmission and high transmission ratio. That is why the TCA researches are important for the geometrical analysis of them. The mechanical parameters could be defined before the manufacturing and the real application.

The aim of this study is to show the correlation between the changing mechanical parameters depending on the axial module. All of the initial parameters are the same except the axial modules which are selected by prescribed gear standards. With the knowledge of the constructional references, all the other geometrical parameters are determined by the GearTeq. The generation of this cylindrical worm surface is determined by mathematical way so the contact points and the surfaces of the worm wheel could also be determined.

CAD models were created by SolidWorks software. It is important to assemble them according to the tooth connection. 
Since three teeth of the worm wheel are connected to the worm at the same time - we did our TCA for each of them.

The main mechanical parameters which have to be analyzed in a TCA are the normal stress and normal deformation. We also made static structural analysis for the research. These results and geometrical effects on the contact zones are determined.

The effects of the pressure of the worm - on the surface of the worm wheel - are calculated by mathematical way. Polygons are used to determine these areas - of which geometries are determined by geometrical calculations (polygon method). The whole surfaces of the worm wheels are also calculated by the same way. Thus, the ratios of areas and perimeters between the whole surfaces and the connecting impressions are calculated in percentages for each connecting tooth in case of the normal deformation and normal stress analysis. That is why it is possible to show the correlations between the percentages and the axial modules.

Based on the average normal deformation and normal stress results, the functions and consequences are determined depending on the modification of the axial module.

The axial and radial deformations are also determined on the surfaces of the teeth with average values. The axial direction is parallel to the axis of rotation of the worm wheel. The radial direction is perpendicular to it. These results were also evaluated depending on the axial modules.

\section{ACKNOWLEDGEMENT}

Project no. TKP2020-NKA-04 has been implemented with the support provided from the National Research, Development and Innovation Fund of Hungary, financed under the 2020-4.1.1-TKP2020 funding scheme.

This research was partly supported by the János Bolyai Research Scholarship of the Hungarian Academy of Sciences.

I, Dr. Sándor Bodzás, would like to express my great respect to Prof. Dr. Tibor Bercsey † (2020) (Budapest University of Technology and Economics, Budapest, Hungary) who provided plenty of consultations on the research topic of worm gear drives to me. He had several publications and wide experience in this topic. He was one of the reviewers of my Ph.D. dissertation who supported my work by his useful remarks.

FUNDING: not applicable

CONFLICTS OF INTEREST/COMPETING INTERESTS: not applicable AVAILABILITY OF DATA AND MATERIAL: not applicable

CODE AVAILABILITY: not applicable

ETHICS APPROVAL: we approve it

CONSENT TO PARTICIPATE: we consent for the publishing

CONSENT FOR PUBLICATION: we consent for the publishing

AUTHORS' CONTRIBUTIONS: we consent for the publishing

\section{REFERENCES}

[1] Zs. Balajti: "Kinematikai hajtópárok gyártásgeometriájának fejlesztése”, Ph.D. dissertation, Miskolc, University of Miskolc, 2007.

[2] T. Bercsey: "Globoid csiga és sík fogfelületü hengeres kerék kapcsolódási viszonyainak vizsgálata", University doctoral dissertation, Budapest, 1971.

[3] T. Bercsey: "Toroidhajtások elmélete", Candidate dissertation, Budapest, 1977.

[4] Dudás: "The Theory and Practice of Worm Gear Drives", Kogan Page US., USA, 2004. 
[5] P. Horák: "Körívprofilú csigahajtópárok tribológiai vizsgálata", PhD dissertation, BME, Budapest, 2003.

[6] F. L. Litvin: "Gear geometry and applied theory", Englewood Cliffs, Prentice Hall, NJ., 1994.

[7] F. L. Litvin, A. Fuentes: "Gear Geometry and Applied Theory", Cambridge University Press, 2004., ISBN 9780521815178

[8] I. Sz. Krivenko: "Novüe tipü cservjacsnüh peredacs na szudah”, Izd. Szudoszrovenie, Leningrád, 1967.

[9] C. Bolos, M. Ciotea, B. Bucur, V. Bolos: "Modeling the double worm-face gears", Journal of Industrial Design and Engineering Graphics, Volume 10, 2015

[10] M.V. Chernets: "Prediction Method of Contact Pressures, Wear and Life of Worm Gears with Archimedean and Involute Worm,Taking Tooth Correction into Account", Journal of Friction and Wear, 2019, Vol. 40, No. 4, pp. 342-348., ISSN 1068-3666, DOI: $10.3103 / \mathrm{S} 1068366619040032$

[11] K. Kawasaki, I. Tsuji: "Machining method of large-sized cylindrical worm gears with Niemann profiles using CNC machining center", International Journal of Advanced Manufacturing Technology, 2019, 104:3717-3729, https://doi.org/10.1007/s00170-019-04076-4

[12] J. Shon, N. Park: "Study on the influence of gear hobbing and shaft misalignments on the geometric interference of cylindrical worm gear set", Journal of Mechanical Engineering Science, 2016, DOI: 10.1177/0954406216671543

[13] V. Goldfarb, N., Barmina: "Theory and Practice of Gearing and Transmissions", Springer, p. 450, ISBN 978-3-319-19740-1, DOI 10.1007/978-3-319-19740-1

[14] V. Goldfarb, E. Trubachev, N. Barmina: “Advanced Gear Engineering, Springer”, p. 497, ISBN 978-3-319-60398-8, DOI 10.1007/978-3-319-60399-5

[15] Q. Meng, Y. Zhao, J. Cui, Z. Yang: "Meshing theory of mismatched ZC1 worm drive", Mechanism and Machine Theory, Elsevier, 2020, https://doi.org/10.1016/j.mechmachtheory.2020.103869

[16] V. Vullo: Gears, Volume 1: "Geometric and Kinematic Design", Springer, p. 880, ISBN 978-3030-36501-1, https://doi.org/10.1007/978-3-030-36502-8

[17] J. Sohn, N. Park: "Geometric interference in cylindrical worm gear drives using oversized hob to cut worm gears", Mechanism and Machine Theory, Elsevier, 2016, http://dx.doi.org/10.1016/j.mechmachtheory.2016.02.002

[18] Z. Zeng, Y. Chen, B. Chen, X. Du, C. Li: "Meshing performance investigations on a novel pointcontact hourglass worm drive with backlash-adjustable", Mechanism and Machine Theory, Elsevier, 2020, https://doi.org/10.1016/j.mechmachtheory.2020.103841

[19] S. Moaveni: "Finite Element Analysis, Theory and Application with ANSYS", Pearson Education Limited, 2015, ISBN 10: 0-273-77430-1, p. 928

[20] Z. Terplán: “Gépelemek IV.”, Kézirat, Tankönyvkiadó, Budapest, 1975., p. 220.

[21] S. P. Radzevich: "Dudley's Handbook of Practical Gear Design and Manufacture", Third edition, CRC Press, p. 656, ISBN 9781498753104

[22] L. Dudás: "Modelling and simulation of a new worm gear drive having point-like contact", Engineering with Computers, 2012, Engineering with Computers: Volume 29, Issue 3, 2013., pp. 251-272, ISSN 0177-0667

[23] F. L. Litvin, I. Gonzalez-Perez, K. Yukishima, A. Fuentes, K. Hayasaka: "Design, simulation of meshing, and contact stresses for an improved worm gear drive", Mechanism and Machine Theory, Elsevier, Volume 42, Issue 8, 2007, p. 940-959, https://doi.org/10.1016/j.mechmachtheory.2006.08.005

[24] T. Nieszporek, R. Gołębski, L. Soos: "Analysis of the worm-wheel toothing accuracy", Technical Gazette, 24(4), 2017, 993-1000., https://doi.org/10.17559/TV-20160422094400

[25] S. Bodzás: "Kúpos csiga-, tányérkerék-, és szerszám felületek kapcsolódásának elemzése", $P h D$ dissertation, University of Miskolc, 2014, p. 154.

[26] K. Bányai: "Hengeres csigák gyártásgeometriája és ellenőrzése”. University Doctoral Dissertation, Miskolc, 1977.

[27] D. Maros, V. Killman, V. Rohonyi: “Csigahajtások”, Müszaki Könyvkiadó, Budapest, 1970. 
[28] S. Bodzás: "Computer-aided design and loaded tooth contact analyses of bevel gear pair having straight teeth by different loaded torques", Mechanics \& Industry 21 : 1 Paper: 109, 2020, https://doi.org/10.1051/meca/2019076

\section{NOMENCLATURE}

\begin{tabular}{|c|c|c|}
\hline$\vec{v}_{1 R}^{(12)}$ & $\left(\mathrm{mm} / \mathrm{min}^{-1}\right)$ & Relative velocity vector \\
\hline $\overrightarrow{n_{1 R}}$ & & Normal vector of the surface in $\mathrm{C}_{1 \mathrm{R}}$ coordinate system \\
\hline $\overrightarrow{r_{1 R}}$ & & Placement vector of the moving points of the profile curve \\
\hline $\overrightarrow{r_{P}}$ & & Position vector of the generating curve of the tool surface \\
\hline$M_{1 R, P}$ & & Coordinate transformation matrix (transforms $C_{P}$ to $C_{1 R}$ ) \\
\hline $\mathrm{O}_{1 \mathrm{R}}, \mathrm{O}_{\mathrm{P}}$ & & Origins of the appropriate coordinate systems \\
\hline $\begin{array}{l}\mathrm{C}_{1 \mathrm{R}} \quad\left(\mathrm{x}_{1 \mathrm{R}}, \quad \mathrm{y}_{1 \mathrm{R}},\right. \\
\left.\mathrm{z}_{1 \mathrm{R}}\right)\end{array}$ & & Rotational coordinate system related to the driver gear wheel \\
\hline $\mathrm{C}_{\mathrm{P}}\left(\mathrm{x}_{\mathrm{P}}, \mathrm{y}_{\mathrm{P}}, \mathrm{z}_{\mathrm{P}}\right)$ & & Tool coordinate system of generating curve \\
\hline $\mathrm{x}, \mathrm{y}, \mathrm{z}$ & $(\mathrm{mm})$ & Coordinates \\
\hline$\eta, \theta$ & & Internal parameters of the helicoidal surface \\
\hline $\mathrm{m}_{\mathrm{ax}}$ & $(\mathrm{mm})$ & Axial module \\
\hline $\mathrm{p}_{\mathrm{d}}$ & $(\mathrm{mm})$ & Diametral pitch \\
\hline $\mathrm{p}_{\mathrm{dn}}$ & $(\mathrm{mm})$ & Normal diametral pitch \\
\hline $\mathrm{m}_{\mathrm{n}}$ & $(\mathrm{mm})$ & Normal module \\
\hline $\mathrm{p}_{\mathrm{x}}$ & $(\mathrm{mm})$ & Worm lead of thread \\
\hline $\mathrm{t}_{0}$ & $(\mathrm{~mm})$ & Circular pitch of the worm-wheel \\
\hline$\gamma_{\mathrm{m}}$ & $(\mathrm{mm})$ & Lead angle \\
\hline $\mathrm{f}^{\prime}$ & & Addendum coefficient \\
\hline$c^{*}$ & & Clearance coefficient \\
\hline r' & & Fillet coefficient \\
\hline $\mathrm{z}_{1}$ & & Number of threads \\
\hline $\mathrm{Z}_{2}$ & & Number of teeth of the worm-wheel \\
\hline $\mathrm{d}_{01}$ & $(\mathrm{~mm})$ & Pitch diameter of the worm \\
\hline $\mathrm{d}_{02}$ & $(\mathrm{~mm})$ & Pitch diameter of the worm-wheel \\
\hline$d_{a 1}$ & $(\mathrm{~mm})$ & Outside diameter of the worm \\
\hline$d_{a 2}$ & $(\mathrm{~mm})$ & Outside diameter of the worm-wheel \\
\hline $\mathrm{a}$ & $(\mathrm{mm})$ & Center distance \\
\hline $\mathrm{b}_{2}$ & $(\mathrm{~mm})$ & Face width of the worm-wheel \\
\hline $\mathrm{L}$ & $(\mathrm{mm})$ & Worm length \\
\hline$\alpha_{\mathrm{ax}}$ & $\left({ }^{\circ}\right)$ & Pressure angle \\
\hline$\alpha_{\mathrm{n}}$ & $\left({ }^{\circ}\right)$ & Normal pressure angle \\
\hline$h_{\mathrm{a} 1}$ & $(\mathrm{~mm})$ & Addendum of the worm \\
\hline$h_{\mathrm{a} 2}$ & $(\mathrm{~mm})$ & Addendum of the worm-wheel \\
\hline$h_{f 1}$ & $(\mathrm{~mm})$ & Dedendum of the worm \\
\hline$h_{f 2}$ & $(\mathrm{~mm})$ & Dedendum of the worm-wheel \\
\hline $\mathrm{S}_{\mathrm{ax} 1}$ & $(\mathrm{~mm})$ & Tooth thickness of the worm \\
\hline $\mathrm{S}_{\mathrm{ax} 2}$ & $(\mathrm{~mm})$ & Tooth thickness of the worm- wheel \\
\hline $\mathrm{r}$ & $(\mathrm{mm})$ & Fillet radius \\
\hline $\mathrm{j}$ & $(\mathrm{mm})$ & Backlash \\
\hline $\mathrm{i}$ & & Transmission ratio \\
\hline$q$ & & Diameter ratio \\
\hline M & $(\mathrm{Nm})$ & Load torque \\
\hline
\end{tabular}


$\mu$

TCA

CAD
Friction coefficient

Tooth Contact Analysis

Computer Aided Designing 